\title{
Dollar Funding and Firm-Level Exports
}

\author{
Antoine Berthou ${ }^{1}$,Guillaume Horny ${ }^{2}$ \& \\ Jean-Stéphane Mésonnier ${ }^{3}$
}

\author{
March 2018, WP \#666
}

\begin{abstract}
How do financial frictions in currency markets affect firm-level exports? We bring new answer to this question by looking at a recent episode in the summer of 2011 when the cost of US dollar funding increased markedly for European banks and their clients. Our analysis relies on a unique dataset of matched banks and exporters located in France. We measure the exposure of individual exporters to the 2011 dollar funding shock using information about their lending banks' crossborder US dollar liabilities before the shock. Controlling for observed and unobserved firm-level factors and product-destination-level demand effects, we find robust evidence that more exposed firms reduced more their exports to the United States in the twelve months that followed the shock. The magnitude of this financial trade cost is equivalent to a counterfactual rise in US tariffs by 2 to 5 percentage points. Finally, we document various transmission channels related to firms' natural hedging, market power, relations with US banks in France or use of financial instruments to hedge. ${ }^{4}$
\end{abstract}

Keywords: foreign currency borrowing, trade finance, firm-level exports, euro-area crisis.

JEL classification: F14, F42, G21, E58.

\footnotetext{
${ }^{1}$ Banque de France (e-mail: antoine.berthou@banque-france.fr)

${ }^{2}$ Banque de France (e-mail: guillaume.horny@banque-france.fr)

${ }_{3}^{3}$ Banque de France (e-mail: jean-stephane.mesonnier@,banque-france.fr)

${ }^{4}$ We thank Jae-Bin Ahn, Thorsten Beck, Emilia Bonaccorsi (discussant), Catherine Fuss (discussant), Michiel Gerritse, Neeltje van Horen, Victoria Ivashina, Beata Javorcik, Kalina Manova, Thierry Mayer, Steven Ongena, Veronica Rappoport (discussant), Tim Schmidt-Eisenlohr and Amir Sufi for fruitful discussions, as well as the participants in the 2017 DEGIT conference, ETSG 2017 meeting, 2017 congress of the EEA, 2016 AFSE congress, the 2016 Belgian Financial Research Forum hosted by the National Bank of Belgium, the Fourth Research Workshop of the Task Force on Banking Analysis for Monetary Policy of the MPC, and in seminars at the Banca d'Italia, the Banque de France, the IMF, the Federal Reserve Board, the University of Groningen and at the University of Bicocca for their feedback. The views expressed herein are those of the authors and do not necessarily reflect those of the Banque de France or the Eurosystem.
}

Working Papers reflect the opinions of the authors and do not necessarily express the views of the Banque de France. This document is available on publications.banque-france.fr/en 


\section{NON-TECHNICAL SUMMARY}

Exporting to some destinations entails an exposure of the exporter to foreign exchange risk. For instance, when selling goods to the United States, European firms overwhelmingly receive payments in US dollars instead of euros. Setting the price of its exports in the currency of the importer exposes the firm to a currency mismatch, when the export revenues are denominated in US dollars while the debt raised to fund working capital is denominated in euros. This problem is exacerbated by the long payment delays typical of international trade transactions. A common hedging practice in such a case is for the exporter to borrow today the value of its future export revenues in the importer's currency (or to purchase hedging derivative contracts) from a bank. The success of such a strategy then crucially depends on the capacity of the exporter's bank to grant foreign currency funding at a reasonable price. In times of stress in the foreign exchange market, the ability of exporting firms to find foreign currency financing may therefore be constrained, which adds a financial trade cost to other trade costs such as foreign tariffs or transportation. Accordingly, the ability of the domestic financial system to smoothly provide exporters with the foreign currency they need to fund their activity may prove an important contribution to the country's competitiveness.

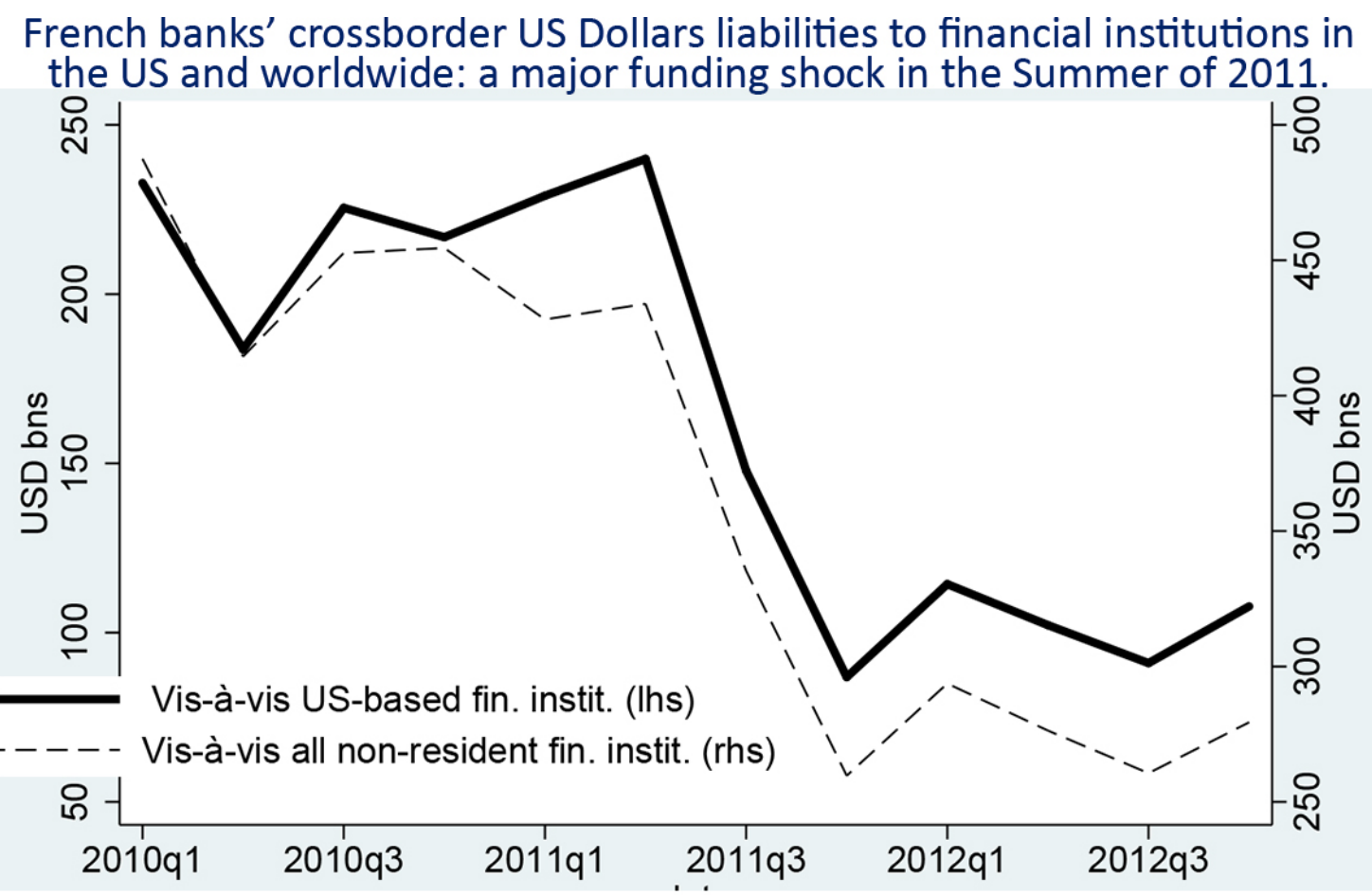

In this paper, we show that shocks increasing exporters' cost of foreign currency funding negatively affect their export performance. Our analysis exploits a large exogenous shock to the cost of US dollar funding faced by French banks and their domestic customers in the second half of 2011. As the euro crisis escalated in 2011, US money market funds started to worry about the creditworthiness of European banking groups. As a consequence, they cut their dollar-denominated exposure to European banks across the board. Meanwhile, heightened tensions in the euro-dollar foreign exchange market 
materialized in sharp deviations from the covered interest parity. Overall, this resulted in an increased cost of dollar funding for European banks and their customers.

We investigate whether this dollar-specific funding shock affected the export performance of French firms to the United States, a market where most imports are priced in US dollars. In order to identify the effects of this shock, we construct an ex ante measure of French exporters' exposure to the 2011 US dollar funding shock using a unique dataset that merges disaggregated information on French banks' cross-border dollar liabilities with exhaustive data on bank-firm credit relationships and firms' exports. We find that more exposed firms reduced their exports to the United States in the twelve months that followed the shock. In the baseline specification, the point estimate shows that an increase in firm-level ex ante exposure to dollar funding by one standard deviation $(2.52$ percentage points) is associated with a reduction in exports to the United States by 3.6 percent relative to other destinations. The effect of the dollar funding shock proves to be strongly non-linear, as firms in the top $33 \%$ of the exposure distribution react about 9 times more than firms in the bottom third. Furthermore, we show that the US dollar funding shock reduced the survival probability of French exporters in the US market. Note that this impact is economically non-negligible: according to our computations, the average impact of this heightened, destination-specific, financial trade cost on French exports to the US is indeed akin to the effect of a counterfactual rise in US tariffs by 2 to 5 percentage points.

\section{Financement en dollars et exportations des entreprises}

\section{RÉSUMÉ}

Comment les frictions financières sur les marchés des changes affectent-elles les exportations au niveau de l'entreprise? Nous apportons une nouvelle réponse à cette question en nous penchant sur un épisode récent de l'été 2011, où le coût du financement en dollars américains a considérablement augmenté pour les banques européennes et leurs clients. Notre analyse s'appuie sur un ensemble de données unique de banques et d'exportateurs appariés situés en France. Nous mesurons l'exposition des exportateurs individuels au choc du financement en dollars de 2011 en utilisant l'information sur les engagements transfrontaliers en dollars américains de leurs banques avant le choc. En contrôlant à la fois pour les facteurs observés et non observés au niveau de l'entreprise et pour la demande au niveau des produits exportés sur chaque marché de destination, nous constatons que les entreprises plus exposées au choc ont réduit davantage leurs exportations vers les États-Unis au cours des douze mois qui ont suivi le choc. L'effet de ce coût financier des exports équivaut à celui qu'aurait une hausse hypothétique des tarifs douaniers américains de 2 à 5 points de pourcentage. Enfin, nous documentons les différents canaux de transmission liés à la couverture naturelle des entreprises, au pouvoir de marché, aux relations avec les banques américaines en France ou à l'utilisation d'instruments financiers de couverture.

Mots-clés : emprunts en monnaie étrangère, financement du commerce international, exportations des entreprises, crise de la zone euro.

Les Documents de travail reflètent les idées personnelles de leurs auteurs et n'expriment pas nécessairement la position de la Banque de France. Ce document est disponible sur publications.banque-france.fr 


\section{Introduction.}

Exporting to some destinations entails an exposure of the exporter to foreign exchange risk. For instance, when selling goods to the United States, European firms overwhelmingly receive payments in US dollars instead of euros (Gopinath et al., 2010). ${ }^{1}$ Setting the price of its exports in the currency of the importer exposes the firm to a currency mismatch, when the export revenues are denominated in US dollars while the debt raised to fund working capital is denominated in euros. This problem is exacerbated by the long payment delays typical of international trade transactions. ${ }^{2}$

A common hedging practice in such a case is for the exporter to borrow today the value of its future export revenues in the importer's currency. The success of this strategy then crucially depends on the capacity of the exporter's bank to grant foreign currency funding at a reasonable price. ${ }^{3}$ In times of stress in the foreign exchange market, the ability of exporting firms to find foreign currency financing may therefore be constrained, which adds a financial trade cost to other trade costs such as foreign tariffs or transportation. Accordingly, the ability of the domestic financial system to smoothly provide exporters with the foreign currency they need to fund their activity may prove an important contribution to the country's competitiveness.

In this paper, we show that shocks increasing exporters' cost of foreign currency funding negatively affect their export performance. Our analysis exploits a large exogenous shock to the cost of US dollar funding faced by French banks and their domestic customers in the second half of 2011. As the euro crisis escalated in 2011, US money market funds started to worry about the creditworthiness of European banking groups. As a consequence, they cut their dollardenominated exposure to European banks across the board (Ivashina et al., 2015). Meanwhile, heightened tensions in the euro-dollar foreign exchange market materialized in sharp deviations from the covered interest parity. Overall, this resulted in an increased cost of dollar funding for European banks and their customers (Sushko et al., 2016). We investigate whether this dollarspecific funding shock affected the export performance of French firms to the United States, a market where most imports are priced in US dollars. In order to identify the effects of this shock, we construct an ex ante measure of French exporters' exposure to the 2011 US dollar

\footnotetext{
${ }^{1}$ Gopinath et al. (2010) show that $87 \%$ of the US total value of imports from France is priced in US dollars, and that the rate of pass-through of exchange rate movements into import prices is disproportionately less important in this case than with exporter currency pricing.

${ }^{2}$ Demir and Javorcik (2014) or Ahn (2015) document the wide use of post-shipment payments and the resulting long payment delays in international transactions.

${ }^{3}$ Exporters can resort to alternative hedging strategies based on derivative contracts (forward contracts, currency options, swaps). Whatever strategies involve a financial contract with the bank, and the cost of hedging is affected by foreign exchange market conditions (e.g., in terms of volatility of the exchange rate or of size of the currency basis.
} 
funding shock using a unique dataset that merges disaggregated information on French banks' cross-border dollar liabilities with exhaustive data on bank-firm credit relationships and firms' exports. We find that more exposed firms reduced their exports to the United States in the twelve months that followed the shock. This impact is economically non-negligible: according to our computations, the average impact of this heightened, destination-specific, financial trade cost on French exports to the US is indeed akin to the effect of a counterfactual rise in US tariffs by 2 to 5 percentage points.

The issue we address here of the financial trade costs associated with the foreign currency denomination of exports has been largely overlooked so far, although anecdotical evidence suggests it is an important concern for internationally active firms. ${ }^{4}$ A plausible reason for this neglect is the difficulty to gather detailed enough data to track convincingly the effects of stressed foreign exchange markets, via the funding problems faced by banks, on exporters' performance in destination markets for which trade credit in foreign currency is required. The richness of our database allows us to perform this exercise properly. Our empirical investigation exploits a unique dataset that covers all individual banks and exporting firms in France over the period from mid-2010 to mid-2012. The data in particular reports individual information on French banks' cross-border borrowings in US dollars from US-based financial institutions, detailed banks' balance sheets, and the universe of credit links between French banks and firms as tracked by the French credit registry. This bank-firm information is then matched with an exhaustive dataset on French exports provided by the French customs, which reports information on firm-level exports by destination and product (aggregated at 4-digits HS product codes) using a single firm identifier.

Our identification strategy relies on constructing an ex-ante measure of the exposure of French exporters to the 2011 dollar funding shock through their banks. To start with, we measure the exposure of French banks to the US dollar funding shock based on their cross-border US-dollar liabilities vis-à-vis the US financial sector. We consider these bank liabilities as a ratio to total bank assets and measure them before the US dollar funding shock in 2011. The bank-level exposure is then linked to exporters using bank-to-firm loan data from the credit register. Our identification assumption is that more exposed French banks were more involved into funding French exporters in US dollars before the shock compared to other banks. We therefore expect that these banks reduced more this funding to their clients as a result of the increase in the cost of cross-border borrowing in US dollars during the shock period. In an unreported

\footnotetext{
${ }^{4}$ Two reports by the French public finance watchdog (Inspection Générale des Finances) warned public authorities in 2012 and 2013 about the difficulties faced by French companies to obtain dollar funding at a reasonable price from their banks (IGF, 2012, 2013)
} 
investigation, we indeed find evidence that French banks with a higher share of cross-border US dollar funding ex-ante, typically global banks, were more specialized into funding French exporters to the United States than other banks, in line with the bank specialization hypothesis developed by Paravisini et al. (2017). Preliminary estimations using bank-firm data also show that firms exporting to the United States received less credit from banks more exposed to USdollar funding ex-ante than from other banks. ${ }^{5}$ This result is consistent with an increase in the cost of US dollar borrowing channelled to firms via the most exposed banks during the period of the shock. At the level of the firm, the US dollar funding exposure variable is constructed as a credit-weighted average of the bank(s) exposure(s), where the weights are computed using the credit shares of each bank in each firm as of June 2011.

The core of our empirical analysis then examines the impact of the US dollar funding shock on firms' export performance in the United States. A testable equation is derived from a partial equilibrium model of trade with oligopolistic competition and C.E.S. preferences, where the financial friction in currency markets enters as a firm-level and destination-specific variable trade cost. In the empirical analysis, the firm-level exposure variable detailed above is used as a proxy for this financial friction. We implement a standard difference-in-difference estimation with continuous treatment, where the more "treated" firms are characterized by a higher exposure to US dollar funding ex-ante.

We take advantage of the richness of our dataset to control for two types of possible confounding effects: unobserved firm-specific shocks and unobserved product-specific demand effects. First, we control for unobserved firm characteristics by taking out the firm-level fixed effect. To do so, our baseline dependent variable is constructed at the firm-product-level as the difference between the growth of exports to the United States and the average growth of exports to all destinations. Using this approach allows to capture all unobserved productivity or supply shocks that may affect a firm's overall export performance. Second, the export equation is estimated using product fixed-effects to control for US-specific demand shocks (relative to other destinations).

In spite of these controls, our estimation strategy still faces a remaining challenge due to some potential assortative matching between firms and banks. For instance, exporters with better export opportunities may be linked to large banks able to supply specific financial products such as funding exporters in foreign currency. We show in Figure 2 below that larger exporters to the US were more exposed to the US dollar funding shock before 2011, meaning that they also favored relations with banks which initially enjoyed an easier access to (cross-border) US

\footnotetext{
${ }^{5}$ The estimation controls for firms' credit demand using firm fixed-effects as in Khwaja and Mian (2008). No differential effect is found when the estimation is performed on firms exporting only to euro area destinations.
} 
dollar funding. This pattern is in line with previous work showing that exporting firms which actively hedge against foreign exchange risk are typically larger firms (Lyonnet et al., 2016), which is consistent with the acknowledged fact that larger and more productive exporters tend to do more pricing-to-market (Berman et al., 2012). In our baseline regressions, we therefore account for the fact that banks are not randomly assigned to firms by including two key characteristics of the ex ante bank-firm relationship(s) as controls: the average size of the banks which lend to a given firm, and the number of banking relationships of each firm. As a robustness check, we also provide additional estimations where "treated" and "non-treated" firms are matched using a propensity score weighting strategy, as proposed by Imbens and Wooldridge (2008). The results are qualitatively the same.

We find that, at the level of French exporters, an ex ante higher exposure to the US dollar funding shock caused a larger relative slowdown of exports to the United States over the 12 months following the shock. In the baseline specification, the point estimate shows that an increase in firm-level ex ante exposure to dollar funding by one standard deviation (2.52 percentage points) is associated with a reduction in exports to the United States by 3.3 percent relative to other destinations. The effect of the dollar funding shock proves to be strongly non-linear, as firms in the top $33 \%$ of the exposure distribution react about 9 times more than firms in the bottom third. Furthermore, we show that the US dollar funding shock reduced the survival probability of French exporters in the US market.

In a robustness section, we proceed to a bunch of additional estimations to test for the stability of our results. We first report a placebo estimation, where we replicate our main empirical specification one period before the shock. This exercise confirms that our measure of firm-level US dollar exposure had no impact on firms' export growth absent the shock, which validates the usual assumption of "ex ante parallel trends". Second, we use an alternative definition of the relative growth of exports to the United States, by using only remote OECD countries outside of Europe and North America in the group of control destinations. These alternative estimations allow us to test for the possibility that our results may be driven by unobserved characteristics of the bank-firm relationship, and also for the heterogeneity among the set of treatment destinations (the United States) and control destinations. Our results are robust to all alternative empirical specifications, including specifications that rely on a propensity score matching to control for the endogenous selection of banks by firms. Considering the absolute growth of exports to the United States instead of the relative growth as a dependent variable leads to similar results as well (whether we control or not for firm-level fixed effects).

We test different transmission channels associated with an exposure to cross-border bank dollar funding that may explain our result. First, we find that firms benefiting from a "natural" 
foreign exchange hedging, i.e. firms with roughly equivalent export and import flows to and from the United States (presumably paid in the same currency), were less affected by the dollar funding shock. Second, we find that low-markup firms, which tend to be smaller firms that more often price their exports in their own currency (i.e. in euros), were less affected than large and more productive exporters, which tend to price their exports in the currency of the importer. Third, we do not find any evidence that the firms that were ex ante in a relationship with an affiliate of a US bank in France were less affected by the shock. Last, we match our main dataset with a survey which was conducted among a sample of European firms in 2008 and asked them to report information about their effective use of currency hedging instruments (such as derivative contracts). We find that the firms which reported in 2008 actually using financial instruments to hedge against exchange rate fluctuations were more badly hit in 2011 by the US dollar funding shock in terms of their export performance to the United States.

Related literature. This paper contributes to the literature that investigates the role of trade finance for exporters. ${ }^{6}$ Trade finance instruments indeed play an important role in facilitating international trade activity, by providing liquidity to exporters who need to finance their working capital, hedge against exchange rate risk, or insure them against the risk of default by importers. There is evidence that financial factors and in particular trade finance contributed to the great trade collapse relative to domestic output in 2008/09 (Ahn, 2011; Ahn et al., 2011; Bricongne et al., 2012; Chor and Manova, 2012). ${ }^{7}$ Schmidt-Eisenlohr (2013), Niepmann and Schmidt-Eisenlohr (2015) and Antràs and Fritz Foley (2015) show that the choice of the contract between the exporter and the importer (open account, cash in advance, or letter of credit) is endogenous and responds to the characteristics of the source and destination countries in terms of financial and legal conditions. Demir and Javorcik (2014) show that exporters tend to grant importers more trade credit in more competitive environments.

Different strategies have been contemplated in order to identify the mechanisms underlying the transmission of financial shocks to firms' trade activities. A main issue is that any quantification of the importance of these channels requires an identification strategy dealing with the endogenous relation between firms' exports and the use of trade finance. Amiti and Weinstein (2011) use information about banks' financial health in Japan to establish a causal impact of trade finance on Japanese firms' export performance, consistent with trade finance mechanisms

\footnotetext{
${ }^{6}$ Evidence of the role of finance for aggregate trade is provided by Berthou (2010) or Manova (2013). There is also evidence that firm-level financial health is related to firms' export and import performance (Bas and Berthou, 2012; Berman and Héricourt, 2010; Muûls, 2015), although the evidence is much debated (Greenaway et al., 2007).

${ }^{7}$ In contrast, Levchenko et al. (2010) challenge this view as they find no conclusive evidence in the case of US that trade finance explained the drop in product-level exports and imports during the early years of the crisis.
} 
related to working capital financing and default risk insurance. Feenstra et al. (2014) rationalize the working capital financing channel in a theoretical framework, and find empirical support based on a sample of Chinese exporters. Paravisini et al. (2015) exploit the experience of the drought of foreign financing of banks in Peru during the Great Recession and identify a causal effect of bank credit on firms' exports at the intensive margin. This last paper highlights the importance played by the bank-lending channel for exports in the case of a developing economy, with foreign banking shocks affecting the stability of the local banks and their credit supply. ${ }^{8}$

Our work instead focuses on the impact of financial frictions in foreign currency markets and the cost of foreign currency funding for exporters. ${ }^{9}$ Based on our theoretical framework and calibrating the elasticity of substitution between varieties using a standard parameter value from the literature, we are able to quantify the effects of the US dollar funding shock in terms of an increase in the financial variable trade cost for exporting to the United States.

Our paper also contributes to the assessment of a largely overlooked central bank instrument, the foreign exchange swap lines between central banks, which have played a key role in smoothing foreign exchange market tensions during the recent financial crises. More precisely, we highlight here the real costs associated with the temporary mispricing of the swap facility between the US Federal Reserve and the ECB, which actually failed to alleviate the dollar funding stress until the beginning of 2012. As such, our paper therefore also relates to the ongoing efforts at assessing the costs and benefits associated with the various unconventional policies engineered by the major central banks during the recent financial crisis (see, e.g., Drechsler et al., 2014; Andrade et al., 2015).

The paper is organized as follows. Section II discusses what happened in the Summer of 2011 and why the dollar funding shock hitting European banks at that time may have constrained French firms' exports in the following quarters. Section III presents our data. Section IV presents preliminary results showing that the negative credit supply shock induced by the dollar funding squeeze transmitted only to exporters to the US dollar area. Section V details our empirical strategy in order to assess the real effects of the US dollar funding shock. Section VI presents our baseline results while section VII provides robustness tests. Transmission mechanisms are analyzed further in Section VIII. The last section concludes.

\footnotetext{
${ }^{8}$ See also Chodorow-Reich (2014) or Cingano et al. (2016) for more evidence on the bank lending channel based on credit register data.

${ }^{9}$ The role of foreign financing in facilitating exports is explored in Berman and Martin (2012) and Manova et al. (2015). Fauceglia et al. (2014) and Lyonnet et al. (2016) provide evidence on the determinants of currency hedging for exporters, while Amiti et al. (2014) show how natural hedging through exports and imports affects the pass-through of exchange rates into export prices.
} 


\section{The 2011 dollar funding shock as a quasi-natural experiment.}

To identify the effects on exports of the destination-specific financial trade cost that is associated with US dollar pricing, we exploit a major shock on US dollar funding faced by European banks and their clients in the Summer of 2011. During this phase of the euro area sovereign debt crisis, soaring yields of Spanish and Italian sovereign bonds heightened concerns of investors worldwide about the creditworthiness of European banks loaded with sovereign bonds issued by crisis-hit governments. As a consequence, some US-based financial institutions (notably many US money market funds) shunned European and French banks. As Figure 1 shows, this led to a sharp drop in the crossborder US dollar liabilities of banks in France vis-á-vis US-based financial institutions (by some USD 150 bns, from a total of some USD 250 bns before the shock), while the price of dollar borrowing for French banks simultaneously rocketted. Importantly, the Figure also shows that, over the 12 months following the Summer of 2011, French banks could not compensate for the lost US dollar funding from US institutions by borrowing more from institutions located in other financial centers (such, e.g., as London).

The sharp increase in the cost of US dollar funding for European residents during this episode in 2011 is apparent in a substantial deviation from the Covered Interest Parity (CIP) between the euro and the US dollar at that time. Miu et al. (2012) or Sushko et al. (2016) document that the increase in the cost of synthetic US dollar funding through USD-EUR swaps reached almost 200 basis points in 2011. Ivashina et al. (2015) show that the rise in the cost of US dollars for European banks - including French ones - contributed to the reduction of loans in US dollars by European banks to US companies during the period of the Great Recession. Most importantly, they show that the increase in the cost of US dollar funding in the cash market for these banks could not be compensated by borrowing "synthetic" US dollars, i.e. euro borrowing combined with a currency Swap, due to the increase in the currency basis mentioned above. ${ }^{10}$

Importantly, the mechanism at play here is different from a standard bank lending channel as in Peek and Rosengren (1997) affecting the capacity of banks to lend to all of their clients, irrespective of the currency-denomination of loans. In contrast, the shock that we exploit in this paper is exclusively related to the cost of US dollar funding for French exporters. In the case of our model below, this shock would act as an increase in trade costs to export to the United States by $+2 \%$ for French exporters (like a $2 \%$ increase in the tariff duty on US imports from France). We elaborate on this number at the end of the paper, and show that it matches well the

\footnotetext{
${ }^{10}$ Ivashina et al. (2015) show that the increase in the cost of synthetic US dollars is mainly explained by two ingredients: i) capital constraints faced by arbitrageurs and ii) an increasing demand for swaps on the other side of the trade. This mechanism led to the deviation of from the CIP in Euro-dollar the swap market.
} 
CIP basis in the US dollar/Euro swap market during the shock period.

In the empirical analysis presented below, we consider two consecutive 12-month periods that surround the drop in cross-border dollar lending to non-US banks. First, the period before the shock, denoted by $T_{0}$ in what follows, covers the 12 months from July 2010 to June 2011. The second period, which we denote $T_{1}$, covers the 12 months from July 2011 to June 2012 . Our empirical strategy then exploits the richness of the granular dataset presented in the next section.

\section{Data.}

\section{A. Sources and definition of the main variables.}

Our empirical analysis builds on the merger of four data sets: banks' cross border liabilities in US dollars, bank's balance sheets, bank-firm credit exposures and customs data for all exporting firms in France.

Banks' dollar funding is measured using granular data from the BIS Locational Banking Statistics (LBS). This data is collected by the Banque de France every quarter at the banklevel, for more than 300 banks in France. The LBS dataset provides us with information on the currency decomposition of bank's liabilities, along with the country and sector of their counterparts. Foreign-based financial institutions account for almost all the crossborder dollar liabilities of banks resident in France from 2011 to 2013. We measure banks' exposure to a shock on their dollar funding as the ratio of their cross-border dollar funding from US based financial institutions as of June 2011 over their total assets. Balance sheet items for banks located in France are provided by the French Supervisory Authority.

Bank-firm credit links are identified with loan data from the credit register held by the Banque de France. A bank has to report its credit exposure to a given firm as soon as it is larger than EUR 25,000. Our measure of the bank-firm credit exposure adds up the loans already granted (drawn credits) and the bank's commitments on credit lines (or undrawn credits). From June 2010 to July 2011, this dataset covers information on more than 2.5 millions of bank-firms relationships, corresponding to more than 1.7 million of firms, with monthly frequency.

Exporting firms are identified with the French Customs' data. This data details firm-level French exports by product at the 8-digits level of the Combined Nomenclature (NC8) and destination country with monthly ferquency. We aggregate this data at the 4-digits level in order to avoid the noise related to frequent changes in the product nomenclature at the 8-digits level. Keeping the product-detail in our data will allow us to account for product-level demand shocks in the empirical specification, and to identify the supply side effect of the dollar funding 
shock. The reporting threshold for exporting to extra-EU destinations is set to 1,000 euros per transaction, so we virtually observe all transactions. Inside the EU, firms exporting less than 460,000 euros per year are not required to report detailed information about their exports and are not observed in the main data. This implies that many small exporters to the EU are missing from the dataset. ${ }^{11}$ Given that we focus our attention on firm-level exports to the United States (and use the average exports growth to other markets as a control), our estimations are not really affected by this threshold. We sum up monthly export flows into cumulated 12-month flows corresponding to our two periods of interest (pre- and post-shock).

These four datasets are merged using either bank identifiers (BIC codes) or common firm identifiers (SIREN codes). We apply a few conditions on banks, firms and bank-firm relationships during the merger. Importantly, the sample of banks is restricted to French banks with strictly positive cross-border dollar liabilities vis-à-vis US financial institutions as of June 2011. ${ }^{12}$ Focusing on French individual banks with positive crossborder USD liabilities before the shock is necessary for our purpose since we cannot guess the potential exposure of banks without any direct such liabilities in the absence of precise data on internal currency markets within banking groups. Indeed, the latter banks may or may not depend on other entities in the same banking group for their USD funding, so that we cannot determine their exposure to the dollar funding shock. In contrast, banks with positive crossborder USD liabilities before the shock are reasonably assumed to usually rely on their own crossborder funding sources and therefore to suffer from the 2011 dollar funding shock. This restriction however comes at a cost since it entails dropping 112 French individual institutions which account for some $25 \%$ of credit to firms. Furthermore, one relatively large bank that has been restructured between July 2010 and June 2012 is excluded, and we also drop a few small banks whose total assets increased by more than $50 \%$ or less than $-50 \%$ over 12 months after June $2011 .^{13}$ Regarding cleaning conditions imposed on firms, we then exclude firms whose total credit growth lies in the bottom $2 \%$ or top $2 \%$ of the credit growth distribution over the two periods considered. Finally, we exclude exports growth observations in the bottom $1 \%$ or top $1 \%$ of the firm-destination-product exports growth distribution.

The key variable we use in our quasi-experimental design is the firm-level exposure to a dollar funding shock. We measure the firm-level exposure as the average of the bank-level exposures, weighted by the outstanding amount of credit (loans and unused credit lines) in

\footnotetext{
${ }^{11}$ The reporting threshold was 150,000 euros up to 2010 . Importantly, we harmonize this threshold to make it constant over the time period considered.

${ }^{12}$ We will use information about US banks' affiliates and branches in France in a robustness estimation. Foreign banks in France account however for less than $8 \%$ of total credit to firms according to the credit registry.

${ }^{13}$ These outliers make up all together less than $1 \%$ of total credit to firms
} 
each bank-firm relationship. Hence, a firm's exposure depends on the exposure of banks it is connected to, and on these banks' relative weights in the firm's total bank credit. All exposures are measured by their average over the 12-month period prior to the shock, namely from July 2010 to June 2011.

\section{B. Descriptive statistics.}

We end-up with a sample of 5,318 exporters and 22 banks belonging to 6 banking groups, observed from July 2010 to June 2012. The banks in this final sample make up $99 \%$ of the total cross-border bank borrowing in US dollar from monetary and financial institutions in the US. They also account for nearly $60 \%$ of bank credit granted to non-financial firms in France.

Table 1 provides descriptive statistics as of June 2011 on the cross-border dollar liabilities for the 22 French banks in our sample. These US dollar liabilities are quite small in banks' balance sheet: the median bank exposure accounts for less than $0.1 \%$ of total assets. The distribution of this ratio is however highly heterogenous across French banks, as the average ratio of US dollar liabilities over banks' total assets is about 1\%, with the first quartile of banks reporting almost no exposure to US dollar funding, and the 9 th decile at $3.75 \%$.

Table 2 provides information on the exporters connected to these banks. The distribution of their exposure to a dollar funding shock through their banks is skewed to the left, with a relatively long right tail. Hence, many exporters are either weakly connected to exposed banks or connected to banks being weakly exposed. Most of the exporters are connected to multiple banks before the shock. Indeed, less than a half of the exporters borrow from only one single bank. From July 2010 to June 2011, exporters were on average connected to 3.6 bank. $^{14}$

Table 3 describes the heterogeneity in exporters characteristics according to their exposure. On average, firms with an above median exposure are connected to more banks : 1.3 on average, compared to 1.0 for exporters with below median exposures. These "treated" exporters also tend to be related to larger banks, compared to exporters in the "control" group. Furthermore, "treated" firms export larger volumes, which is consistent with the positive correlation between the exporters' size in terms of total exports to the United States and the treatment intensity (see Figure 2). Exporters with above-median exposures are therefore not fully similar to those with below-median exposures. To assess these differences, the third column of Table 3 reports a measure of the gap in the distribution of the covariates across treatment status. For each covariate, we compute the difference in their average values between "treated" exporters and the "control" exporters, normalized by the square root of the sum of the variances. Imbens and

${ }^{14}$ This statistic refers to the overall number of banks. Among the 22 selected banks, exporters were connected to 2 banks on average. 
Wooldridge (2008) suggest that a normalized difference above 0.25 indicate a lack of overlap in the distribution of covariates across treatment and control group, hence estimates fragiles to a change in the specification. According to this statistic, both "treated" and "control" exporters differ substantially in the values of their covariates. We deal with this issue in several ways. Firstly, we control for the characteristics of the bank-firm relationship by including in our main specification controls for the average number of banks, size of the lenders to each firm and exporter size. Secondly, we use propensity score weighting in robustness estimations.

\section{Preliminary investigation: impact of the US dollar funding shock on bank-firm credit.}

We start our empirical investigation by exploring how bank loans to exporters were affected by the US dollar funding shock in 2011. We estimate Equation (1) below, where the dependent variable ( $\Delta \ln$ loans $_{f b, t_{1}}$ ) represents the $\log$ variation of loans by bank $(b)$ to firm $(f)$ between the period of the shock (T1) and the initial period (T0). Our main variable of interest is the banklevel "exposure" to the US dollar funding shock, as defined in the previous section. $X_{b, 2011 Q 2}$ is a bank-specific set of covariates comprising bank size, as measured by banks' total assets, as well as bank-specific capital to assets ratio and interbank liabilities to assets ratio. ${ }^{15}$ As is now standard practice, we control for firm-specific demand by including firm-level fixed effects in our main specification. This conducts us to drop from the estimation single-bank firms, while the estimation relies on the sample of firms with at least two banking relations (Khwaja and Mian, 2008).

$$
\Delta \ln _{\text {loans }} f b, t_{1}=\beta \frac{\text { US } \$ \text { Liabilities viz US MFI }_{b, 2011 Q 2}}{\text { Total Assets }_{b, 2011 Q 2}}+\delta X_{b, 2011 Q 2}+\eta_{f}+\varepsilon_{f b, t_{1}},
$$

Estimation results are reported in Table 5. Overall, we find that, following the mid-2011 dollar funding shock, banks which were ex ante more reliant on US dollar borrowing from US financial institutions decreased more their loans to French exporters to the US, relative to less exposed banks. This result is particularly robust when the estimation includes both the firm-level fixed effects and bank characteristics in column (3). Quantitatively, a higher bank exposure to the US dollar funding shock by 1 percentage point yields a contraction of lending to French exporters in the US by about $0.45 \%$.

\footnotetext{
${ }^{15}$ We drop firms according to the same filters as the ones used for the main exercise. Furthermore, because loanlevel data tend to be volatile, we drop bank-firm relationships with a loan growth above $200 \%$ or below $-50 \%$. The firm sample is therefore smaller than in the baseline estimates.
} 
Importantly, we also find that the credit supply to the firms which export to euro area destinations only does not appear to have been affected by the US dollar funding shock (see column 5 in Table 5). This result supports our assumption that the US dollar funding shock mostly modified the cost of exporting to US dollar destinations - such as the United States - relative to other destinations, and resulted in smaller amounts of credit received by exporters from exposed banks. In the empirical investigation that we detail below, we will use this heterogeneity in terms of treatment across destinations to provide an estimation of the impact of this specific financial friction on firms' exports, while still controlling for other firm-level supply shocks affecting the export performance in all destinations.

\section{Impact of the US-dollar funding shock on French firms' exports: empirical strategy.}

In this section, we detail our empirical strategy . We first present the theoretical background that motivates our empirical model, and then discuss identification issues and how we solve them.

\section{A. Theoretical background.}

We derive our empirical equation from a model of oligopolistic Cournot-competition with CES demand structure, as in Amiti et al. (2016). In this model, the market share of a firm in product $p$, market $j$ and year $t$ can be expressed as :

$$
s_{f p j t} \equiv \frac{v_{f p j t}}{Y_{p j t}}=\left(\frac{p_{f p j t}}{P_{p j t}}\right)^{1-\rho} .
$$

The firm-level Cost-of-Insurance-and-Freight (CIF) export price is expressed as:

$$
p_{f p j t}=\frac{\sigma_{f p j t}}{\sigma_{f p j t}-1} c_{f t} \tau_{p j t} \theta_{f j t},
$$

and the firm-level market share is determined by three types of shocks : the firm-time marginal cost of the firm $c_{f t}$, which is typically unobserved; a destination-product-time "trade costs" shock related for instance to foreign tariffs or exchange rate movements $\tau_{p j t}$; and a firmdestination specific trade $\operatorname{cost} \theta_{f j t}$. While it is standard to include the first two shocks in heterogeneous firms trade models - see for instance Demidova and Rodríguez-Clare (2013), the third shock implies that firm relative sales in a specific market may also relate to firm-destination specific shocks. They may relate to preferences for firms' products in foreign markets (the appeal of foreign consumers for a French brand) or simply to firm-specific frictions for exporting 
to certain markets (distribution costs, financial frictions etc.).

In this model with oligopolistic competition, the perceived demand elasticity of the firm is defined as:

$$
\sigma_{f p j t}=\left(\frac{1}{\eta} s_{f p j t}+\frac{1}{\rho}\left(1-s_{f p j t}\right)\right)^{-1} .
$$

This elasticity varies with the market share of the firm : a higher market share is associated with a lower perceived price elasticity of demand, and a higher markup $\frac{\sigma_{f p j t}}{\sigma_{f p j t}-1} . \rho$ is the elasticity of substitution across varieties within industry and it is defined as an exogenous parameter; $\eta$ is the elasticity of substitution across industries and is also exogenous.

Finally, $P_{p j t}$ is the price index and determines the level of competition in market $\mathrm{j}$ and product $\mathrm{p}$, while $Y_{p j t}=\sum_{f} v_{f p j t}$ is the aggregate demand (total sales in product $p$, market $j$ and year $t$ ).

Our main variable of interest is $\theta_{f j t}$, which we will interpret throughout the empirical investigation as a financial friction affecting the CIF export price to destination $j$ by firm $f$. As discussed above, frictions in foreign exchange markets are expected to affect the cost of exporting to some destinations. In particular, the dollar funding shock in 2011, which reduced the availability of US dollars for European banks and their clients, is expected to have increased the cost of exporting to the United States relative to other destinations. In our empirical investigation, we need, however, to control for other shocks (firm productivity shocks, demand shocks etc.) that could also affect firm-level exports, and bias our estimation of the impact of financial frictions on firm-level exports.

Taking logs of (2) and first-differentiating, we obtain the following equation:

$$
\Delta \ln v_{f p j t}=(1-\rho) \Delta \ln c_{f t}+(1-\rho) \Delta \ln \theta_{f j t}+\gamma_{p j t}+\zeta_{f p j t}+\varepsilon_{f p j t},
$$

where $\zeta_{f p j t}=(1-\rho) \Delta \ln \left(\frac{\sigma_{f p j t}}{\sigma_{f p j t}-1}\right)$ is a firm-product-specific shock associated with markup adjustment, and $\gamma_{p j t}=(1-\rho)\left(\Delta \ln \tau_{p j t}-\Delta \ln P_{p j t}\right)+\Delta \ln Y_{p j t}$ is a product-destination fixed effect. $\varepsilon_{f p j t}$ is the error term.

While the product-destination fixed effects in Equation (3) allows controlling for demand shocks, or shocks related to competition in the foreign market for each product, we still need to control for shocks on the marginal $\cos t c_{f t}$ and for $\zeta_{f p j t}$, which represents the change in markups. Note that the markup level of the firm in each of its destinations is not constant here due to the oligopolistic market structure of the model. With monopolistic competition, this term would be time-invariant and product-specific, and therefore it would be captured by the 
product-destination fixed effects.

To control for the firm-specific unobserved shock, $c_{f t}$, we use a transformation of the exports growth variable using the firm-level average exports growth in its different markets $\left(\Delta \widetilde{\ln }_{f p j t}=\Delta \ln v_{f p j t}-\Delta \overline{\ln v_{f p . t}}\right)$. This allows to explain the relative exports growth of the firm in a given market by the relative change in the firm-specific trade cost for that specific market. We obtain a new expression of the relative exports growth of firm $f$ to destination $j$ for product $p$, which is not affected by the firm-specific shock to the marginal cost:

$$
\Delta \widetilde{\ln v}_{f p j t}=(1-\rho) \Delta \widetilde{\ln \theta}_{f j t}+\widetilde{\gamma}_{p j t}+\widetilde{\kappa}_{f p j t},
$$

where $\widetilde{\ln }_{f j t}=\ln \theta_{f j t}-\overline{\ln \theta}_{f . t}$ is the relative firm-specific trade cost (financial friction) to destination $\mathrm{j}$ and product $\mathrm{p} ; \widetilde{\gamma}_{p j t}=\gamma_{p j t}-\bar{\gamma}_{p . t}$ is a transformation of the destination-product fixed effect; $\widetilde{\kappa}_{f p j t}=\kappa_{f p j t}-\bar{\kappa}_{f p . t}$ is a transformation of the error term including the unobserved change in markup, with $\kappa_{f p j t}=\zeta_{f p j t}+\varepsilon_{f p j t}$.

Assuming a general functional form for firm-destination specific financial frictions, with $\theta_{f j t}=\delta_{f j t}^{-v}$ and $\delta$ a shock on the supply-side affecting the cost of currency funding of firm $f$ in the currency of country $j$ at time $t$, we obtain a new equation where the value of exports to a destination is now related to the friction in the currency market $\delta$ :

$$
\Delta \widetilde{\ln v}_{f p j t}=\beta \Delta \widetilde{\ln \delta}_{f j t}+\widetilde{\gamma}_{p j t}+\widetilde{\kappa}_{f p j t}
$$

The parameter $\beta=v(\rho-1)$ that we will estimate is a combination of the elasticity of substitution across varieties of the same product $(\rho)$ and the slope of the credit supply curve in a foreign currency $v$.

\section{B. The 2011 dollar funding shock as a quasi-natural experiment.}

From the previous expression in Equation (5), we expect that financial frictions affecting the cost of funding in the currency of country $j$ will tend to reduce firm-level exports to that destination. The challenge here for identification is to identify financial frictions that are specific to some currencies and not to others. As discussed above, the US dollar funding shock that French and other European banks suffered in 2011 provides us with a quasi-natural experiment affecting mostly those exporters that relied more, through their banks, on cross-border USdollar financing before 2011. Our main hypothesis is that financial frictions associated with US dollar funding by European banks increased the firms' cost of exporting to the United States relative to other destinations. 
In all our estimations, the treatment variable will be the "Dollar Funding Exposure" of each exporter prior to the shock in 2010. Throughout the analysis, the estimated equation will therefore read:

$$
\Delta \widetilde{\ln v}_{f p j 2011 / 10}=\beta \text { Dollar Exposure } f 2010+\widetilde{\gamma}_{p j 2011 / 10}+\widetilde{\kappa}_{f p j 2011 / 10}
$$

\section{Identification issues.}

The unbiased estimation of parameter $\beta$ requires that the dollar exposures of firms are uncorrelated with the error term in Equation (6). Taking the notations of equation 5, this requires that $\operatorname{corr}\left(\widetilde{\ln \delta}_{f j t}, \widetilde{\kappa}_{f p j t}\right)=0$. In other words, the matching of exporters with banks has to be unrelated to firm-market characteristics that appear in the error term. The fact that firms' markup change $\zeta_{f p j t}$ appears in the error term implies that this assumption may not be verified, if for instance the firm-level markup and the treatment variable are correlated $\left(\operatorname{corr}\left(\widetilde{\ln \delta}_{f j t}, \widetilde{\zeta}_{f p j t}\right) \neq 0\right)$. Larger firms may indeed have higher markups in a specific market and these firms may have a higher incentive to subscribe a financial instrument with some specific banks. A negative coefficient on parameter $\beta$ could result from less performing firms being matched with banks providing specific financial instruments. Unobserved demand shocks affecting firm-level exports to some markets may also introduce a bias in the estimation of parameter $\beta$, if for instance these shocks are correlated with the bank-firm relationship.

Our identification strategy addresses these potential problems as follows. Firstly, unobserved demand shocks are captured using US-product-time fixed effects $\left(\widetilde{\gamma}_{p j 2011 / 10}\right)$. These fixed effects therefore allow to control for changes in demand for certain goods in the United States, which may be correlated with French exporters' borrowing in US dollars from their banks prior to the shock. They also control for nominal exchange rate variations between the US dollar and the euro during the period of the analysis: there was a sharp depreciation of the euro vis-à-vis de US dollar by about 15\% between August 2011 and July 2012. As we will see later, this depreciation however plays against our result, as it improved the competitiveness of French products in the US market. As a result, this channel should have increased, rather than decreased, the relative export performance in the United States.

Secondly, the transformation of the export growth variable controls for unobserved firmspecific shocks. This allows us to control for firm-level covariates that would impact the exports to all destinations, such as changes in firm default risk. As explained above, the transformation of the firm-level exports variable allows to get rid of the firm-level time-varying fixed effect that would explain export growth in all markets. By considering a firm's exports growth in the US 
market relative to its average exports worldwide, we ensure that these unobserved firm-level characteristics, which could possibly be correlated with the bank affiliation, are not driving our main result.

As additional firm-level characteristics may affect both the bank-firm relation and simultaneously the export performance in the United States, we complete our baseline specification with additional controls for firms' characteristics. In particular, we control for the number of banks supplying credit to each firm, as having more banks may offer the possibility to switch to alternative credit suppliers. We also control for the average size of the banks operating with each firm, as operating in international markets may require to be in relation with global banks, which are able to provide the firm with different financing instruments (such as letters of credit) beyond the simple provision of credit US dollars.

We additionally control for the size of the firm in terms of total exports, as the exports growth of French firms in the US market relative to their average market may also be related to their size (if for instance smaller exporters do export less frequently in the US market and have, for this reason more volatile relative exports growth rates). Last, to control more directly for the estimation bias identified in the error term of Equation (6) above, we include as well a control for the theoretical markup of the firm related to exports in the US market. Remember that the error term of the estimation is affected by the unobserved markup specific to each firm and destination $\left(\kappa_{f p j t}=\zeta_{f p j t}+\varepsilon_{f p j t}\right.$.). As having a higher markup implies that, in the model, firms are changing less frequently their prices and are therefore more exposed to the currency risk, these firms may have an incentive to hedge more against exchange rate fluctuations by borrowing from their banks in US dollars. We first compute the theoretical perceived demand elasticity of the firm, based on its share in total French exports to the United States by HS2 product category, in the 12 months prior to the shock ( $\rho$, the elasticity of substitution across varieties within industry, is set to be equal to $5 ; \eta$, the elasticity of substitution across industries is set to be equal to 1). We then construct the firm-specific markup as follows: Markup fpjt $_{1}=$ $\ln \left(\frac{\sigma_{f p j t 0}}{\sigma_{f p j t 0}-1}\right)$, and introduce the log of this variable as a control in our main estimation strategy.

In order to assess the robustness of our estimations, we complete our baseline empirical strategy by additional tests to account for the role played by confounding factors that may introduce some biases in our results. In these robustness estimations, we deal with mainly two biases. Firstly, an obvious threat to our estimations is the role played by the selection of exporters by banks. This selection may generate a correlation between our treatment variable and the relative exports growth of firms in the US market. We provide two alternative tests, a placebo regression based on the period prior to the shock and a propensity score weighting, which confirm or reinforce the baseline results. Secondly, our estimation strategy detailed 
above relies on the comparison of firms' exports growth in different and heterogeneous markets (e.g. the United States and Belgium), whereas we would ideally like to compare exports performance in similar markets. We deal with this problem by selecting only remote OECD destinations excluding North-America (Australia, New Zealand, South-Korea, Japan, Israel and Chile) in the group of control destinations. There again, our results are reinforced rather than attenuated in this robustness check.

Lastly, we will also report the results of an estimation where we consider all potential destinations for each exporter and express the dependent variable as the absolute variation of exports to that destination. We interact the treatment variable with a dummy identifying the US destination, so that the interaction term therefore becomes the main variable of interest. We also control for the firm-level fixed effect in this estimation. One set of estimations will also be reported when we consider the absolute variation of firm-level exports to the United States only during the period of the shock, thus ignoring the potential impact of the shock to other destinations.

\section{Baseline results.}

\section{A. Firms' exports growth to the United States.}

We detail in this section our main results regarding the impact of the 2011 US dollar funding shock on firm-level relative exports growth to the United States. The baseline equation that we estimate using the matched banks-exporters data is the following:

$$
\Delta \widetilde{\ln v}_{f p, u s, t_{1}}=\beta \text { Exposure }_{f, u s, t_{0}}+\widetilde{\gamma}_{p, u s, t_{1}}+\widetilde{\varepsilon}_{f p, u s, t_{1}} .
$$

The main variable of interest in this equation is the firm $(f) \log$ variation in HS 4-digits product-level exports to the United States between June 2011 and June 2012: $\Delta \ln \widetilde{v}_{f p, u s, t 1}$ (for each date, export values are cumulated over 12 months). As discussed in the empirical methodology section, expressing the dependent variable in relative terms as a "ratio" (i.e. the exports growth to the United States relative to the exports growth to control destinations) allows correcting for unobserved firm-specific shocks affecting exports growth to all destinations. Our main variable of interest is the ex ante dollar funding exposure of the firm. As firms with a higher dollar-funding exposure through their banks are also more vulnerable to dollar funding shocks, we expect a negative impact of dollar funding exposure on exports.

We report in Table 6 the estimation results from different variants of Equation (7) where we progressively include bank and firm controls. In the first column, we only control for HS 
4-digits product fixed effects accounting for product-specific demand shocks. In column (2) we introduce controls for the firm's banking relationships: the log number of banks in relation with firm $f$, and the average size of the banks in relation with this firm. In column (3) we additionally control for other firm-level characteristics, namely the theoretical markup of the firm (a transformation of the market share in the US for product $p$ ) and the size of the firm in terms of total exports. Finally, in the last column, we also control for the banks' US-dollar receivables in the United States in the period before the shock (T0), in order to account for the possibility that the US dollar funding shock also affected firm-level exports due to direct financing of the importer by the exporter's bank ("buyer's credit").

Estimation results presented in Table 6 show that firms' relative exports growth to the United States during the shock period was strongly negatively related to their ex ante dollar funding exposure. The effect becomes stronger as we include more controls into the estimation, with an elasticity of about -1.3 in the most conservative estimation (column 5). The average bank size of firms has a positive impact on firm-level relative exports growth to the United States in two out of four estimations where this control is included, which may reflect some selection of exporters by large banks based on their performance. Controlling for the average size of exporter' banks tend to increase the size of the effect of US dollar funding exposure on relative exports growth in the United States (columns 1 and 2), which implies that omitting this control would induce a positive bias in the estimation of our main parameter of interest. Other firm-level controls have a non-significant impact on relative exports growth of firms. This finding was expected due to the transformation of the dependent variable, as taking the exports growth of the firm to the United States relative to the exports growth to the average destination eliminates the firm-level fixed effect.

The effect of the US dollar funding shock on relative exports growth to the United States is highly significant and economically meaningful: given our estimated elasticity, an increase in firm-level exposure to the dollar funding shock by one standard deviation (about 2.5 percentage points, see Table 2) is associated with a reduction in exports to the United States by 3.3 percent. The estimated elasticity also implies that firms with the highest exposure to the dollar funding shock (about 6.3\%) reduced their relative exports to the United States by $8.5 \%$ compared to firms with low exposure operating in the same industry.

\section{B. Non-linear effect of US dollar funding exposure.}

We complete our baseline estimation results by testing for the impact of the US dollar funding shock on French firms' exports to the United States for those firms with the highest dollar 
funding exposure (the top 33\% of exposures in the data), relative to firms with an intermediate exposure (second third of exposures) and firms with only a weak exposure (bottom 33\%). Descriptive statistics on our sample of exporting firms as reported in Table 2 indeed show that the measure of firm-level exposure to the dollar funding shock is highly non-linear, with a median exposure at $0.47 \%$ and the 90th percentile at $6.4 \%$. This non-linearity results from the high degree of concentration of the French banking system, with few global French banks highly exposed to US dollar funding from the United States before the eurozone sovereign debt crisis.

To account for this non-linearity, we create three dummy variables which identify firms having ex ante a high, moderate, or low exposure to US dollar funding, and include them into our baseline empirical specification instead of the linear definition of the US dollar funding exposure. The dummy variable identifying weakly exposed firms is omitted from the estimated equation, so that the results for the other two dummy variables can be interpreted relative to low exposure firms.

Estimation results are reported in Table 7. They confirm that the negative impact of the dollar funding shock concentrated on firms with the highest ex ante exposure: these firms (the top third of US dollar funding exposure) reduced their relative exports performance in the US by about $11 \%$ (column 5) compared with firms with a low exposure. Firms with an intermediate exposure to dollar funding reduced their relative exports performance by about $6.6 \%$ relative to weakly exposed firms, but the elasticity obtained for this category of French exporters is only weakly (or not) significant. Overall, these results confirm that the dollar funding shock that affected few but highly exposed French banks in July 2011 had a strong negative impact on the relative export performance of their clients towards the US in the 12 months following the shock.

\section{Export survival in the US market.}

Whereas the previous results focus on the firm-level exports growth, the US dollar funding shock may have also affected the survival of exporters in the US market. In heterogenous firms trade models, such as Melitz (2003), an increase in the marginal cost of exporting is expected to affect both the intensive margin of exports (the exports value of a firm for a product and a destination) as well as the extensive margin of exports (the export probability). The increase in the marginal cost of exports associated with the dollar funding shock in July 2011 may have therefore reduced the exports probability of French firms in the US market, on top of the relative exports value of highly exposed firms.

To test for this transmission channel, we estimate the Equation (8) below, where the depen- 
dent variable $\left(\right.$ Survival $_{f p, u s, t_{1}}$ ) is a dummy equal to 1 if the firm continued exporting product $p$ to the United States during the shock period, and 0 otherwise (we consider here only those firm-products exported in the initial period T0):

$$
\Delta \text { Survival }_{f p, u s, t_{1}}=\beta \text { Exposure }_{f, u s, t_{0}}+\widetilde{\gamma}_{p, u s, t_{1}}+\widetilde{\varepsilon}_{f p, u s, t_{1}} .
$$

Estimation results are reported in Table 8. In Columns (1) and (2), we report estimation results based on a linear probability model estimated with OLS and HS 4-digits product fixed effects. The results confirm that the dollar funding shock reduced the export probability of the most exposed firms, consistently with an increase in the marginal cost of exporting to the United States for these firms. This result remains valid when we control for banks' US dollar loans to the non-financial sector in the United States. Interestingly, the effect of this variable, which we interpret as a "buyer's credit", is negative and highly significant: French exporters may have been forced to stop exporting, as the capacity of their banks to finance directly the importer was reduced during the shock period.

In columns (3) and (4) of the Table, we report estimation results obtained based on a probit estimator instead of the linear model with OLS. As controlling for a large number of fixed effects can be problematic in a probit estimation, we include in the estimated equation HS 2digits product dummies instead of HS 4-digits product dummies. This raises marginally the number of observations, as HS4 products exported by only one firm are now included in the estimation. Marginal effects are reported at sample mean. The results in columns (3) and (4) of Table 8 confirm previous estimation results based on the OLS estimator: firms more exposed to the US-dollar funding shock had a weaker probability to continue exporting during the shock period, compared with less exposed firms. In quantitative terms, taking into account the elasticity obtained on the exposure variable in the probit estimation without controlling for buyer's credit (-0.8 in column 3), a one standard deviation increase in firm-level exposure to US dollar funding before the shock (about 2.5 percentage points) reduced the probability of survival of the firm-product in the US market by about $2 \%$ in the 12 months after July 2011. Firms in the top $10 \%$ of exposure (exposure $=6.4 \%$ ) faced a lower probability of survival in the US market by about $5.1 \%$ relative to the least exposed firms. 


\section{Robustness estimations.}

\section{A. Placebo in 2010.}

As discussed in the empirical methodology section, a threat in our estimation may come from firms with smaller relative exports growth in the US market being related to more exposed banks ex ante. Our main estimation strategy controls for unobserved firm-specific shocks thanks to the ratio approach, while controlling for the average size of banks in relation with exporters allows to account for the assortative matching between large banks and large exporters. As shown in baseline estimations, controlling for the average size of banks allows correcting for a positive bias in our estimations, which would otherwise undermine the estimated impact of the US dollar funding shock on firms' relative exports in the United States.

Unobservable characteristics to the bank-firm relation may though still have an effect on our estimations. To assess this possibility, we proceed to a placebo estimation where we consider as the dependent variable the relative export performance in the US of French firms one period ahead of the shock. In this estimation, the exports growth rate is defined as the log variation of cumulated exports between the period T0 (12 months between July 2010 to June 2011, i.e. before the shock) and period t-1 (12 months between July 2009 to June 2010). ${ }^{16}$ As the US dollar funding shock is posterior to period T0, we expect that the US dollar exposure of French exporters had no impact on their relative exports performance in the United States before the period of the shock.

Estimation results of this placebo estimation are reported in Table 9. As in the baseline estimation, we report the estimation results based on different empirical specifications where we control for HS4 product fixed effects only (column 1), then introduce banks controls (column 2), firm controls (columns 3 and 4) and finally controls for the banks' loans to non-financial corporations in the United States (column 5). Those results clearly show that no effect of the US dollar funding exposure on French firms' relative exports to the United States can be recorded before the period of the shock: the coefficient is negative but it is never statistically significant. This result therefore rejects that assortative bank-firm matching based on unobservables have been driving our main results.

\footnotetext{
${ }^{16}$ In the baseline estimation, instead, we considered so far the $\log$ variation of exports between periods T1 (the treatment period) and period $\mathrm{T} 0$.
} 


\section{B. Propensity score weighting.}

To complete this robustness analysis, we provide additional results based on a propensity score weighting. As discussed in Section 3, Table 3 shows that firms with an above median exposure tend to export more than those with an exposure below median. Furthermore, firms with above median exposure are related to more banks, which are themselves larger. Such discrepancy in the covariates implies that there are "treated" exporters for which we have no counterfactuals. Inference regarding these observations is fragile, because it relies on modelling assumption rather than on information conveyed by the data. Note that such misled inferences would need to be specific to the shock period, as the placebo estimation shows that no effect of the US dollar funding on export performance can be found outside the period of the shock.

We use a Propensity Score Weighting empirical strategy so as to improve the overlap in the covariates across treated and control groups (see for instance Imbens and Wooldridge (2008)). We assign firms to two groups, depending on whether their exposures are above or below the median. We then compute for each firm it's propensity score, namely the probability to be assigned to the group of higher than median exposures, conditional on firms' characteristics, banks' characteristics, and their interactions. We restrict to observations with a score ranging from 0.1 to 0.9 , since observations out of this range have no counterfactuals in the data. Finally, we replicate the baseline estimates by weighting each observation either by the inverse of the propensity score for those assigned to the treated group, or the inverse of one minus the score for those in the control group. This reduces the impact on the estimates of the two types of observations whose counterfactuals are nearly absent in the data: those in the treated group with a high probability of being treated, and those in the control group with a low probability of being treated. Conversely, we amplify the impact of observations whose counterfactuals are likely to be prevalent in the sample, namely observations in the treated group with a low probability of being treated and those in the control group with a high probability of being treated.

Table 10 reports the results obtained based on the implementation of the propensity score weighting strategy. Compared to our baseline estimates, the negative impact of the US dollar funding exposure on relative exports performance during the shock period is slightly reinforced: in our preferred estimation, the coefficient of interest on the exposure variable is -1.44 (column 5), compared with -1.33 in baseline estimates. Our main results therefore do not seem to be quantitatively affected by the heterogeneity of firms in the treatment and control groups, suggesting that the baseline econometric strategy already controls for this empirical issue. With this elasticity, our estimations imply that a one standard deviation increase in the US dollar 
funding exposure reduced firm-level relative exports to the United States by $3.6 \%$. The $10 \%$ of the most exposed firms reduced their relative exports performance by $9 \%$ relative to the $10 \%$ of least exposed firms.

\section{Accounting for heterogeneity between treatment and control destinations.}

Our main empirical strategy developed in the paper relies on defining the exports growth of firms' exports to the United States relative to the exports growth to the average destination of the firm. A limitation to this approach is that we are potentially comparing different markets that may be subject to different types of supply shocks at the firm-level. For instance, a firm may use different strategies to sell and distribute its goods to large remote destinations such as the United States, compared with European Union markets. The way the exports activity is financed for these destinations may also be different, as exporting to euro area countries does not require dealing with the exchange rate risk, while exporting to geographically distant destinations involves longer payment delays and exposes exporters to payment risks (Berman et al., 2013).

To account for this heterogeneity in the group of "treated" (the United States) and "control" destinations (the average destination of each exporter), we restrict in this robustness analysis the group of control destinations to non-Europe OECD countries (Australia, New-Zealand, Chile, Israel, Japan and South-Korea) and exclude North-American destinations (Canada and Mexico) that may have been contaminated by the US dollar funding shock. Only those firms in our sample exporting to at least one of these destinations are included in the analysis. The average growth rate of exports is computed for these destinations only, and the dependent variable is computed as a difference between the exports growth of French firms to the United States for product $p$ between period $\mathrm{T} 1$ and $\mathrm{T} 0$ and the average growth rate of exports of the same firm towards the group of OECD destinations defined above. This robustness exercise has two virtues: firstly, it accounts for the heterogeneity in between the treated and control destinations as discussed above; secondly, it restricts the analysis to more similar firms being able to export towards at least two remote OECD destinations: the United States and one of the control OECD destinations.

We replicate our baseline estimations using this alternative definition of the dependent variable, and report the estimation results in Table 11. Compared with baseline estimations, the elasticities obtained are larger in absolute terms compared with those in the baseline estimation. In our preferred estimation, where all banks and firms controls are included, the elasticity (-3.07) implies that a one standard deviation increase in the exposure to cross-border US dollar 
funding before the shock reduced firm-level exports by $7.6 \%$ during the shock period. The $10 \%$ of the most exposed firms reduced their relative exports growth to the United States by $19.6 \%$ relative to the least exposed firms.

\section{Other robustness checks.}

In our main empirical approach, the dependent variable is constructed as the difference between the exports growth of exporters to the United States relative to other (control) destinations: the

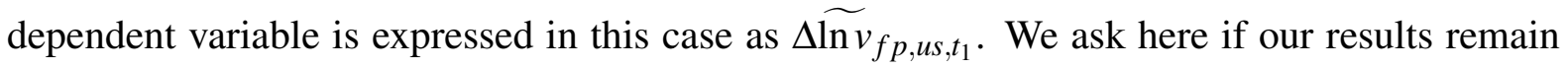
valid when we deviate substantially from this strategy, and simply use the exports growth to destination $j$ as the dependent variable: in this case we express the dependent variable as $\Delta \ln v_{f p, u s, t_{1}}$.

We start by considering all potential destinations for French exports. With this configuration, the information for individual firms exporting to more than one destination is repeated in the panel. All this firm-level information will be captured by firm-level fixed effects, and the identification will be obtained thanks to an interaction variable between the exposure to the US dollar funding shock and a dummy variable identifying the United States as a destination. The estimated equation is the following:

$$
\Delta \ln v_{f p j, t_{1}}=\beta \text { Exposure }_{f t_{0}} \times D_{j=U S}+\gamma_{p j t_{1}}+\xi_{f t_{1}}+\varepsilon_{f p j t_{1}} .
$$

In Equation 9, all firm-level variables including the firm-level exposure variable Exposure ${ }_{f t_{0}}$ are captured by the firm-fixed effects $\xi_{f t_{1}}$. Destination-product shocks in each year are captured by the destination-product fixed effect: $\gamma_{p j t_{1}}$. The coefficient of interest $\beta$ is identified by introducing an interaction term between the firm-level exposure to dollar funding ex ante and a dummy variable identifying the United States as a destination: Exposure $f_{t_{0}} \times D_{j=U S}$. This approach is conceptually similar to our main approach, which consists in taking the difference between the firm-level exports to the United States and the average exports growth of a firm across its destinations.

The results obtained from the estimation of Equation 9 are reported in Table A1 in the Appendix section. These results confirm qualitatively and quantitatively those obtained in our baseline estimation: the coefficient $\beta$ in the first three columns ranges from -0.94 to -1.42 and is always statistically significant. The coefficient obtained on interactions of the US dollar exposure at the firm-level with dummies for other NAFTA destinations (Mexico and Canada) or Eurozone destinations are not significant. This confirms that the effect of the US dollar funding shock faced by French exporters concentrated on firm-level exports to the US (columns 
3 and 4). If we focus on a group of destinations composed of the United States and other OECD destinations (excluding Europe, Turkey, and other North-America countries), the effect is slightly increased (col. 5). Finally, the non-linear effect of the US dollar exposure on exports to the United States is confirmed (col. 6).

In a second step, we consider only the United States in the set of destinations. In this case, the dependent variable is expressed as $\Delta \ln v_{f p, u s, t_{1}}$. This strategy has both advantages and disadvantages. It allows us to estimate an absolute impact of the US dollar funding shock on exports to the US, i.e. not relative to other destinations. We can therefore test if the effect identified in previous estimations was driven by contemporaneous shocks for exporting to other destinations. On the negative side, this strategy does not allow to control for the firm-level fixed effect as in previous estimations (baseline and robustness checks with all destinations and firmlevel fixed effect above).

$$
\Delta \ln v_{f p, u s, t_{1}}=\beta \text { Exposure }_{f t_{0}}+\gamma_{p, u s, t_{1}}+\varepsilon_{f p, u s, t_{1}} .
$$

We estimate Equation 10 and present the estimation results in Table A2. The results with the OLS estimation (both the linear and non-linear effects of the US dollar funding exposure) confirm our baseline results: firms more exposed to US dollar funding ex ante reduced their exports to the United States relative to less exposed firms during the period of the shock (col. 1 and 2). These estimation results are confirmed in the estimation that relies on a Propensity Score Weighting. This strategy allows to correct for the unobserved heterogeneity in our estimations, which is all the more important as we do not control here for firm-level fixed effects. The results from this estimation confirm and even reinforce the results from the OLS estimation, as the elasticity is even higher. Overall, this robustness check confirms that the effect of the US dollar funding shock on exports is not explained by a simultaneous shock occurring in third destinations, and reflects well an increase in the cost of exporting to the United States.

\section{Transmission mechanisms.}

In this section, we test for the role of various transmission channels that may explain our main empirical result. We firstly test for the role of firm-level imports, which may have been affected by the US dollar funding shock with potential spillovers on firms' exports. Secondly, we test for the role of the natural hedging through the balance between firm-level exports and imports. Thirdly, we investigate the role of the pricing-to-market behavior that relates to the market power of the firm. Fourthly, we show some evidence on the role played by foreign banks, and in particular the exposure to affiliates or branches of US banks located in France. 


\section{A. The imports channel.}

Our main result could be explained by the strong complementarity between firm-level imports of inputs and their export performance. Using firm-level data for France, Bas and Strauss-Kahn (2014) show that indeed, using more of foreign inputs raises firm-level exports growth. As importing intermediate inputs from abroad may require a payment in US-dollars, constraints on US-dollar funding in the summer of 2011 may have reduced import opportunities from countries such as the United States. French firm-level exports to the United States could have been affected indirectly through a negative supply shock on imported intermediate inputs, rather than directly through the US-dollar funding of exports.

To test for the relevance of this hypothesis, we first run the same regression as in our baseline estimation for exports, but we now look at firm-level relative imports from the US instead of relative exports to the US. The dependent variable is constructed using the same strategy as in the case of exports: $\widetilde{\ln m}_{f p, u s, t_{1}}$ is the difference between a firm's imports growth of product $p$ (HS4) from the United States and it's average imports growth. We estimate Equation (11)

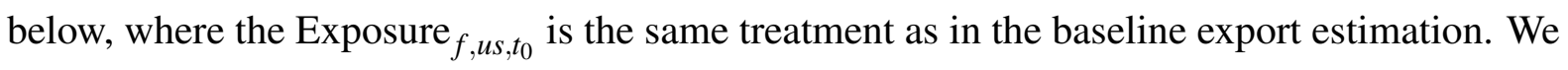
also control for HS-4 product fixed effects in all estimations. We then introduce additional controls for the characteristics of the banks linked to each importer (number of banks, average bank size) as well as information related to firm size (total imports or total employment). Note that we consider the whole population of French firms importing from the US and linked to the "treated" banks in our sample, and not specifically the population of French firms importing from the US and having in addition an export activity to the US as well. This strategy allows us testing for the import mechanism, without introducing a selection in the population of firms reporting export or import activities.

$$
\widetilde{\ln m}_{f p, u s, t_{1}}=\beta \operatorname{Exposure}_{f, u s, t_{0}}+\widetilde{\gamma}_{p, u s, t_{1}}+\widetilde{\varepsilon}_{f p, u s, t_{1}}
$$

The results reported in Table 12 rule out any impact of the US-dollar funding shock on firm-level relative imports from the US. We find that indeed, the coefficient on the exposure variable is positive in all estimations, although not significant. The coefficients on the control variables are also non-significant.

We complete the analysis by providing a direct test for the hypothesis that the use of foreign inputs imported from the US could have amplified the response of firm-level exports to the US due to dollar funding exposure during the shock period starting in June 2011. To do so, we replicate our baseline estimation and include an interaction term between the US-dollar funding exposure and four import variable: the import status of the firm (a dummy variable), 
the log total imports of the firm, the status of importer from the US (a dummy variable), and the $\log$ total imports of the firm from the US. Each variable is measured using information from period T0, i.e. the twelve months preceding the shock in June 2011. We estimate Equation (12) below, where the variable Import $_{f, t 0}$ refers in each estimation to one of the four import variables detailed above.

$\Delta \widetilde{\ln v}_{f p, u s, t_{1}}=\beta_{1}$ Exposure $_{f, u s, t_{0}}+\beta_{2}$ Exposure $_{f, u s, t_{0}} \times \operatorname{Import}_{f, t 0}+\beta_{3} \operatorname{Import}_{f, t 0}+\widetilde{\gamma}_{p, u s, t_{1}}+\widetilde{\boldsymbol{\varepsilon}}_{f p, u s, t_{1}}$.

Estimation results are presented in Table 13. Overall, they confirm the negative impact of the US-dollar funding exposure on firm-level relative exports growth to the United States, with the exception of column (1) of the table where the coefficient $\beta_{1}$ is negative but loses significance. Interaction terms with the import status dummy variable, or total imports, are in general non-significant. The exception is the interaction term between US-dollar funding exposure and the total import value from the US in period T0, which is positive and significant at $10 \%$. This result contradicts the hypothesis that greater constraints on the import side (due to increasing difficulties to finance imports in US-dollars) would have reduced exports growth, since in that case we would instead expect a negative coefficient on the interaction term.

Here, the positive coefficient on the interaction term between the treatment variable and the imports value from the US is more consistent with the idea that importing from the US helps exporters to hedge against exchange rate fluctuations. We test more specifically for this alternative story in the next section.

\section{B. The role of natural hedging through imports.}

As discussed in introduction, firm-level exports to destinations such as the United States often requires pricing the exported good in the foreign currency, which exposes the exporter to adverse changes in the exchange rate. Borrowing today from a bank the amount of future export revenues in US dollars therefore allows firms hedging against unanticipated nominal exchange rate fluctuations. The firm-level exposure to these exchange rate fluctuations, however, also depends on the "natural hedging" of the firm, which may also import goods priced in the same currency as exports. When the amount of receivables in US dollars is similar to the amount of payments expected in the same currency, the firm has no need to hedge against unanticipated exchange rate fluctuations through currency borrowing. We therefore expect that firms being naturally hedged against exchange rate fluctuations were less affected by the US-dollar funding shock faced by French banks in 2011. 
Although we do not observe French firms' payments and revenues in US dollars, we do observe whether a firm exports to, or imports from the United States at a given date. As shown by Gopinath et al. (2010), a majority of US imports from France is denominated in US dollars, and this is true also for US exports to France. We construct a proxy for the currency mismatch of firm $f$ as the absolute value of the difference between a firm's exports and imports from the US, over half of the sum of exports and imports with the US in period T0 :

$$
\text { Mismatch }_{f, t 0}=\frac{\left|v_{f, u s, t 0}-m_{f, u s, t 0}\right|}{0.5^{*}\left(v_{f, u s, t 0}+m_{f, u s, t 0}\right)}
$$

Descriptive evidence presented in Table 4 shows that firms operating in different sectors are differently exposed to the possibility of a currency mismatch, as exporters are weakly involved into importing from the United States. On the one hand, in sectors such as the food industry, firms tend to be more exposed to exchange rate fluctuations and currency mismatch, as only few firms in this sector import inputs from the United States when they export their goods to the United States: the average mismatch measures is equal to 2, which implies that on average, exporters to the US do not import from the US. On the other hand, in sectors such as the aircraft industry, firms are much less exposed to exchange rate fluctuations as they tend to both export to and import from the United States, which offers them a natural hedge against exchange rate fluctuations if transactions are denominated into US dollars. In this sector, the average measure of mismatch equals 1.4. Similar pattern can be observed in the ships industry. Interestingly, in most sectors, there exists some heterogeneity in terms of the firm-level currency mismatch, which we will exploit for identification. For instance, in the aircraft industry, firms in the first quartile of the mismatch distribution report a value of 0.9 , while firms in the third quartile report a value of 1.9 , meaning that this sector is composed of exporters with respectively low and high exposure to exchange rate fluctuations.

We complete previous estimations firstly by estimating our baseline export equation separately for firms characterized by a low currency mismatch (the Mismatch f $_{, t 0}$ variable is below the median value among the whole population of exporters), or a high currency mismatch (the Mismatch $_{f, t 0}$ variable is above the median value among the whole population of exporters). Estimation results reported in Table 14 (columns 1 and 2) indicate that exporters characterized by a low currency mismatch in US dollars were weakly affected by the US dollar funding shock in 2011 (the coefficient on the Exposure variable is negative but not significant) whereas exporters with a high degree of currency mismatch were more severely affected by the shock (the coefficient on the exposure variable, -1.8 , is significant at $5 \%$ and above coefficient obtained when the whole population of exporters is considered, about -1.3). 
In order to test for the robustness of this result, we re-estimate our baseline equation over the whole population of firms by including this time an interaction term with the mismatch variable (see Equation (B)). The coefficient obtained on this interaction term, and reported in column (3) of Table 14, is negative as expected but non-significant.

$$
\begin{aligned}
\Delta \widetilde{\ln v}_{f p, u s, t_{1}}= & \beta_{1} \text { Exposure }_{f, u s, t_{0}}+\beta_{2} \text { Exposure }_{f, u s, t_{0}} \times \text { Mismatch }_{f, t 0} \\
& +\beta_{3} \text { Mismatch }_{f, t 0}+\widetilde{\gamma}_{p, u s, t_{1}}+\widetilde{\varepsilon}_{f p, u s, t_{1}} .
\end{aligned}
$$

To account for the possible non-linear effect of the currency mismatch variable on exports during the dollar funding shock period, we defined three dummy variables, identifying firms in the bottom $33 \%$ of the mismatch distribution (variable "dummy mismatch T1"), firms in the top $33 \%$ of the mismatch distribution (variable "dummy mismatch T3"), and firms in the intermediate category of mismatch distribution (variable "dummy mismatch T2"). We then reestimated Equation (B) by using this time three interaction terms, one for each of the mismatch dummy variables. Estimation results reported in column (4) of Table B confirm that the effect of currency mismatch in US dollars on exports, during the US-dollar funding shock, is highly non-linear. The largest negative impact is obtained for firms belonging to the top 33\% in terms of currency mismatch, i.e. firms exporting to the United States but reporting no or little imports from the United States during the initial period T0. We do not find any effect of the exposure variable, in this estimation, for firms belonging to the first and second groups in terms of currency mismatch.

In a last estimation reported in column (5), we also account for the role played by firms' integration into more complex value chains. Some French firms exporting a given HS4 product to the United States indeed also import the same product from the US as well. As the type of financing of exports and imports may also be more complex in this case (it might be the case for instance that the firm belongs to a multinational group), these firms may have been less affected by the dollar funding shock. The coefficient on the interaction term in previous estimations may therefore reflect the more complex integration of firms into global value chains rather than a pure currency mismatch mechanism. To account for this possibility, we created a dummy variable identifying firm-product pairs characterized by two-way trade with the United States, and interacted this variable with our main Exposure variable. Results are almost unchanged: firms more exposed to a currency mismatch tend to react more to the dollar funding shock. In this econometric specification, only those firms with the smallest currency mismatch (bottom $33 \%$ of the mismatch distribution) were not affected by the shock, while firms with a medium or high currency mismatch reacted negatively in terms of exports. We find as well that 
firm-product pairs characterized by two-way trade reacted less to the shock, but the estimated coefficient appears non-significant.

Overall, these results support that the currency mismatch mechanism was a key driver of the estimated decline in firm-level relative exports to the United States by the most exposed firms during the dollar funding shock in the summer of 2011.

\section{Exporters' markup and pricing-to-market.}

We explore here a separate mechanism related to the pricing strategy of the firm. As discussed in introduction, previous empirical evidence shows that larger and more profitable exporters tend to do more pricing-to-market, i.e., they tend to leave their prices unchanged consecutive to exchange rate movements (Berman et al., 2012). ${ }^{17}$ They also do more local currency pricing, i.e. the value of the payment in the export contract is set in the currency of the importer (Lyonnet et al., 2016).

More pricing-to-market and local currency pricing among larger and more profitable exporters implies that these firms are also more exposed to the risk of a currency mismatch between export revenues (expressed in foreign currency) and domestic production cost (expressed in home currency). For this reason, the US dollar funding shock in 2011 may have been more detrimental in terms of exports for larger and more profitable exporters.

To test for this alternative transmission channel, we use the information about exporters' theoretical markup and market share in the US market before the shock. The theoretical markup of exporters is defined as a function of its market share among the set of French firms exporting the same product (see the exact definition in the theoretical background section): a higher market share implies a higher markup, as in this case firms are facing a weaker elasticity of demand in the context of a model with Cournot competition. We replicate our baseline estimation based on three sub-samples of firms identified respectively with a low exposure to the US-dollar funding shock ex ante (bottom 33\% of firms with the smallest exposure), an intermediate exposure, and a high exposure (top 33\% of firms with the highest exposure). The estimation results reported in Table 15 indicate that while the firm-level theoretical markup has no effect or a weakly positive effect on the relative exports growth in the United States (columns 1 and 2), the effect becomes strongly negative and highly significant when the estimation is performed based on the group of firms with the highest exposure to the US dollar funding shock (column 3): among exporters that were the most exposed to the shock, firms with a higher markup were more negatively impacted in terms of exports than firms with a lower markup. This result is

\footnotetext{
${ }^{17}$ Berman et al. (2012) show that the pricing strategy of exporters can be rationalized in a model with variable firm-level markups.
} 
consistent with the prediction that more profitable firms were harmed more due to more local currency pricing of their exports in US dollars, which implies a greater need for foreign currency borrowing in order to hedge against exchange rate fluctuations.

To complete this test, we replicate our estimations based on the full sample of exporters. We include in our estimations three dummy variables to account for the non-linear impact of the ex ante exposure to US dollar funding, and interact each of the dummy variables with the theoretical markup (Table 15, column 4) or the observed market share (Table 15, column 5). Estimation results confirm that among firms with an intermediate or high exposure to US-dollar funding before the shock, the decline in terms of the relative exports to the United States was more pronounced among the set of firms characterized by a high markup or a high market share.

\section{The role of foreign banks.}

We explore in this section the role played by foreign banks, and in particular US banks in France, during the US dollar funding shock. This test is motivated by recent works showing that foreign banks play a key role in terms of fostering the international trade activities of firms (Bofondi et al., 2013; Claessens et al., 2017). In a recent work, Bacchetta and Merrouche (2015) show that foreign currency borrowing by Eurozone non-financial corporates increased during the Great Recession, especially from US banks, which may reflect that foreign banks helped to alleviate the financial shock in European economies.

The French credit register data used in our analysis allow us to test directly for the role played by US banks during the episode of the US dollar funding shock in 2011. The credit register data used in the analysis allow us to identify that 14 US banks (branches or subsidiaries) were providing loans to French firms exporting to the United States in 2011, before the shock. Among the 5,318 continuing exporters during the period of the shock, about $11 \%$ had a credit relation with a US bank. Among these firms, credit from US banks located in France represented about $18 \%$ of the total bank credit received (see Table 2).

We test for the role of US banks by introducing in our main empirical specification a control for the ex ante link between exporters and US banks (affiliates or branches) in our sample. The estimation result reported in Table 16, column 1, indicates that while the effect of the firm's exposure to cross-border US dollar funding on relative exports performance is confirmed, no significant effect is obtained due to the ex ante relation with US banks. In column 2, the estimation additionally controls for the interaction between US dollar funding exposure and the ex ante link to US banks. The coefficient on this interaction term is positive but not statistically significant. The estimation therefore does not support the assumption that US banks may have 
helped French exporters to absorb the US dollar funding shock in the summer of 2011.

Estimation results reported in the remaining columns of Table 16 confirm this result with different sets of controls. New relations with US banks tend to be associated with a higher relative growth rate of exports in the United States, while breakups have a negative impact (see column 3); the effects though are hardly significant. Interestingly, relations with banks from Southern Europe (Spain, Italy, Portugal) during the shock period seem to have amplified the shock faced by French exporters, rather than dampened it (column 4). Finally, we use the information based on the share of total credit obtained by French exporters from US banks and interact this variable with the US dollar funding exposure variable, in columns 5 and 6 . While receiving more credit from US banks seems to be associated with a higher relative exports growth to the united States during the shock period, we cannot confirm that receiving more credit from a US bank ex ante may have helped to dampen the negative impact of the high exposure to US dollar funding before the period of the shock on relative exports.

Another possibility is that exporters may have established new relations with US banks during the period of the shock, or expanded their borrowings from US banks during the period of the shock. We test for these mechanisms by considering now as the dependent variable changes in the relationship status of French exporters with US banks (Change T1/T0), a dummy variable for new relations (New), a dummy variable for breakups (Drop), the credit growth with US banks, or the credit growth with US banks relative to French banks.

The analysis here is constrained by the number of observations, as only 88 exporters in our sample created new links with US banks during the shock period, whereas 137 firms stopped borrowing from US banks. Overall, the estimations reported in Table 17 do not support the assumption that French exporters may have developed new relations with US banks during the US dollar funding shock period, or expanded their borrowing from US banks, as the coefficient on our main exposure variable is never statistically significant in these estimations.

\section{E. Survey-based evidence on the use of hedging instruments.}

We test here more specifically for the role played by firm-level demand for hedging instruments. The empirical investigation uses of a survey conducted in 2008 among European firms for several countries including France. ${ }^{18}$ It reports in particular information on the use of financial hedging instruments by firms. The following question is asked to surveyed firms: "How do you deal with the exchange rate risk? Which of the following statements is similar to what your firm do?" (question E17A of the survey). Possible answers are (1) "I use a foreign exchange

\footnotetext{
${ }^{18}$ See the EFIGE webpage at http://bruegel.org/publications/datasets/efige/.
} 
risk protection"; (2) "I do not normally hedge against exchange rate risk"; (3) "The question is not applicable, as I only sell to countries with the same currency of my domestic market" and (4) “Don't know or don't answer".

For the purpose of our empirical investigation, we merged the EFIGE survey with our main dataset and generated a new dummy variable indicating if the firm was using financial hedging instruments in 2008 (the answer to the question above is 1) or not. The final data used in the estimation has much fewer firms than in our main investigation, as we were able to match only 219 exporters with the EFIGE survey. Among these firms 61 reported in 2008 that they were using hedging instruments.

In the empirical investigation, we estimate Equation 14 where we consider only the US destination. As there are much fewer observations than in our main empirical analysis, the dependent variable is expressed as the absolute variation of firm-level exports during the period of the shock, and the product fixed effect is defined for HS 2-digit product categories. The main variable of interest is the interaction term between the foreign dollar funding exposure of the firm and the hedging dummy. In the estimation we will also include controls for the firm side and also for the average bank linked to each firm.

$$
\Delta \ln v_{f p, u s, t_{1}}=\beta \text { Exposure }_{f t_{0}} \times \operatorname{Hedging}_{f, 2008}+\gamma_{p, u s, t_{1}}+\varepsilon_{f p, u s, t_{1}} .
$$

Estimation results reported in Table 18 indicate that the greater exposure to the US dollar funding shock was mostly detrimental to firms reporting that they are using financial instruments to hedge against the exchange rate risk. This result is obtained when we consider separately the samples of firms not using hedging or using hedging in columns (1) and (2) of the table. The result also holds when we consider all firms in the sample and interact the exposure variable with the hedging dummy: the negative sign implies that more exposed firms using hedging instruments were more hardly affected by US dollar funding shock. This result is consistent with a rise in the cost of hedging during the period of the shock, which in our model is reflected by a rise in the financial trade cost to export to the United States.

\section{Quantification of the increase in trade costs.}

As emphasized in the theory section of the paper, our results can be rationalized by an increase in the destination-specific financial trade cost, which is identified by parameter $\theta_{f j t}$ in the empirical model. Given our empirical estimation of the impact of a greater US dollar funding exposure on exports to the United States during the period of the dollar funding shock, it is possible to obtain a "tariff-equivalent" of the shock for French exporters. Given that different 
firms had different exposures to US dollar funding ex ante, the increase in trade cost is firmspecific. For each firm, we obtain an approximation of the increase in trade costs using the following formula:

$$
\Delta \ln \theta_{f j t}=\frac{\beta}{1-\rho} \times \text { Dollar Exposure }_{f, 2010}
$$

We provided throughout the paper a range of estimates for parameter $\beta$ : -1.33 in the baseline estimations; -1.44 using the weighted least squares and -3.07 when using non-European OECD countries in the group of reference destinations. An estimation of the elasticity of substitution $\rho$ between different varieties of the same industry is provided by Berthou and Fontagné (2016). The estimations based on the effect of US import tariffs applied on French exports imply a value of $\rho=3.5$ in a demand system with C.E.S. preferences. The statistical moments of variable Dollar Exposure $_{f, 2010}$ are listed in Table 2.

The results of our quantification exercise are provided in Table 19 for the median exporter to the US in our sample in terms of Dollar funding exposure, the average exporter, the average "treated" exporter above the median of exposure, or the top $10 \%$ among the treated. We also provide a quantification of the trade impact for the top $33 \%$ based on our non-linear estimates.

As discussed above in the paper, the trade impact of the US dollar funding shock is fairly limited for the median exporter in our sample $(-0.63 \%)$, while highly exposed firms were more strongly impacted $(-8.5 \%$ for the $10 \%$ of most exposed exporters, about $-11 \%$ for the top $30 \%$ of exposure if we account for non-linearity in the baseline estimation.) The effects are even similar if we base our quantification on estimations from the Weighted Least Squares (about $9 \%$ for the top $10 \%$ in dollar funding exposure), and larger with non-European OECD countries in the reference group of destinations (about -19.6\%).

Based on these trade effects, we can derive estimations of the variable trade cost equivalent of this financial shock faced by French firms exporting to the United States. For the average treated firm, the financial trade cost for exporting to the United States increased by about $2 \%$, which is in line with the currency basis observed in Euro-USD swap market during the period of the shock and discussed earlier in the paper. For the top $10 \%$ of exposures, the estimates of the increase in trade costs range from $+3.4 \%$ to $+7.8 \%$. Although these quantifications are sensitive to the choice of the estimate of the $\beta$ and $\rho$ parameters, they indicate that financial frictions affecting the cost of funding in US dollars can lead to a substantial increase in the variable trade costs for exporters. 


\section{Conclusion.}

We provided in this paper an investigation of the effects of the US dollar funding shock in the summer of 2011 on French firms' export performance in the United States. The collapse in US dollar cross-border funding faced by French banks during this period, and the strong deviation from the covered interest parity in Euro-USD swap markets during this period, offers a quasi natural experiment to investigate how financial frictions in currency markets may affect the export performance of firms to some - but not all - destinations. Of particular interest is the role played by the cost of currency hedging, which is introduced as a variable financial trade costs in our theoretical setting. We find that a rise in the cost of US dollars funding for exporters can have quantitatively large effects on firms' export performance in a US-dollar destination. Our estimation results indicate that the most exposed French exporters (firms in the top third of the exposure distribution) reduced their relative exports to the United States by about 11 percentage points relative to less exposed firms during the period of the shock. This result remains qualitatively valid, and is even reinforced in quantitative terms when we proceed to alternative estimations based on the Propensity Score Weighting, or when we consider only remote OECD countries in the reference group of destinations. Importantly, no effect of the US dollar exposure is found when we replicate our baseline estimation outside of the period of the shock in a placebo test.

We find empirical support for two transmission mechanisms. Firstly, firms involved into both importing from and exporting to the United States appear to have been less affected by the US dollar funding shock. As importing from and exporting to US dollar destinations such as the United States provides firms with a natural hedging against unanticipated exchange rate fluctuations, these firms rely less on US dollar borrowing from their banks and were for this reason less affected by the rationing of US dollars in the summer of 2011. Secondly, firms with a higher market share (and markup) in the United States suffered more from the rationing of US dollars than smaller and less profitable exporters in the United States. This result can be rationalized by the theoretical relation between the markup of exporters and their pricing strategy, which exposes them to unanticipated exchange rate fluctuations when the price of exports is set in the currency of the importer (local currency pricing). However, we do not provide any evidence that affiliates of US banks located in France may have helped French exporters to absorb the shock. Finally, we show that firms using financial instruments to hedge among exposed firms were more negatively affected by the US dollar funding shock.

Drawing more macroeconomic implications based on our estimated elasticities remains challenging, as less exposed firms were not affected and may have benefitted from the shock if 
for instance competition in the US market declined. French exporters may have also benefitted from the depreciation of the euro vis-à-vis the US dollar during this period. At the microeconomic level, however, these estimates shed new light on the transmission of financial trade shocks to exports.

In policy terms, our results also highlight the real costs associated with the mispriced swap facility opened by the US Federal Reserve and the ECB during the crisis, which failed to alleviate the dollar funding stress until the beginning of 2012. It therefore relates to the ongoing efforts at assessing the costs and the benefits associated with the various unconventional policies engineered by the major central banks during the recent financial crisis. 


\section{References}

Ahn, JaeBin, 2011, A Theory of Domestic and International Trade Finance, IMF Working Papers 11/262.

Ahn, JaeBin, 2015, Understanding Trade Finance: Theory and Evidence from Transaction-level Data, Mimeo.

Ahn, JaeBin, Mary Amiti, and David E. Weinstein, 2011, Trade Finance and the Great Trade Collapse, American Economic Review 101.3, 298-302.

Amiti, Mary and David Weinstein, 2011, Exports and Financial Shocks, The Quarterly Journal of Economics 126.4, 1841-1877.

Amiti, Mary, Oleg Itskhoki, and Jozef Konings, 2014, Importers, Exporters, and Exchange Rate Disconnect, American Economic Review 104.7, 1942-1978.

Amiti, Mary, Oleg Itskhoki, and Jozef Konings, 2016, International Shocks and Domestic Prices: How Large Are Strategic Complementarities?, NBER Working Papers 22119, National Bureau of Economic Research, Inc.

Andrade, Philippe, Christophe Cahn, H. Fraisse, and Jean-Stphane Mésonnier, 2015, Can the Provision of Long-Term Liquidity Help to Avoid a Credit Crunch? Evidence from the Eurosystem's LTROs, Working papers 540, Banque de France.

Antràs, Pol and C. Fritz Foley, 2015, Poultry in Motion: A Study of International Trade Finance Practices, Journal of Political Economy 123.4, 853 -901.

Bacchetta, Philippe and Ouarda Merrouche, Nov. 2015, Countercyclical Foreign Currency Borrowing: Eurozone Firms in 2007-2009, CEPR Discussion Papers 10927, C.E.P.R. Discussion Papers.

Bas, Maria and Antoine Berthou, 2012, The Decision to Import Capital Goods in India: Firms' Financial Factors Matter, World Bank Economic Review 26.3, 486-513.

Bas, Maria and Vanessa Strauss-Kahn, 2014, Does importing more inputs raise exports? Firmlevel evidence from France, Review of World Economics (Weltwirtschaftliches Archiv) 150.2, 241-275.

Berman, Nicolas and Jérôme Héricourt, 2010, Financial factors and the margins of trade: Evidence from cross-country firm-level data, Journal of Development Economics 93.2, 206217.

Berman, Nicolas and Philippe Martin, 2012, The Vulnerability of Sub-Saharan Africa to Financial Crises: The Case of Trade, IMF Economic Review 60.3, 329-364.

Berman, Nicolas, Philippe Martin, and Thierry Mayer, 2012, How do Different Exporters React to Exchange Rate Changes?, The Quarterly Journal of Economics 127.1, 437-492. 
Berman, Nicolas, Jos de Sousa, Philippe Martin, and Thierry Mayer, 2013, Time to Ship during Financial Crises, NBER International Seminar on Macroeconomics 9.1, 225-260.

Berthou, Antoine, 2010, The Distorted Effect of Financial Development on International Trade Flows, Working papers 09, Banque de France.

Berthou, Antoine and Lionel Fontagné, 2016, Variable Trade Costs, Composition Effects and the Intensive Margin of Trade, The World Economy 39.1, 54-71.

Bofondi, Marcello, Luisa Carpinelli, and Enrico Sette, 2013, Credit supplying during a sovereign debt crisis, Temi di discussione 909, Banca d'Italia.

Bricongne, Jean-Charles, Lionel Fontagn, Guillaume Gaulier, Daria Taglioni, and Vincent Vicard, 2012, Firms and the global crisis: French exports in the turmoil, Journal of International Economics 87.1, 134-146.

Chodorow-Reich, Gabriel, 2014, The employment effects of credit market disruptions: firmlevel evidence from the 2008-09 financial crisis, Quarterly Journal of Economics 129, 159.

Chor, Davin and Kalina Manova, 2012, Off the cliff and back? Credit conditions and international trade during the global financial crisis, Journal of International Economics 87.1, $117-133$.

Cingano, Federico, Francesco Manaresi, and Enrico Sette, 2016, Does Credit Crunch Investment Down? New Evidence on the Real Effects of the Bank-Lending Channel, Review of Financial Studies 29.10, 2737-2773.

Claessens, Stijn, Omar Hassib, and Neeltje Van Horen, 2017, The Role of Foreign Banks in Trade, CEPR Discussion Papers 11821, C.E.P.R. Discussion Papers.

Demidova, Svetlana and Andrés Rodríguez-Clare, 2013, The simple analytics of the Melitz model in a small economy, Journal of International Economics 90.2, 266-272.

Demir, Banu and Beata Javorcik, 2014, Grin and Bear It: Producer-financed Exports from an Emerging Market, CEPR Discussion Papers 10142, C.E.P.R. Discussion Papers.

Drechsler, Itamar, Thomas Drechsel, David Marques-Ibanez, and Philipp Schnabl, 2014, Who borrow from the lender of last ressort?, mimeo.

Fauceglia, Dario, Anirudh Shingal, and Martin Wermelinger, 2014, Natural Hedging of Exchange Rate Risk: The Role of Imported Input Prices, Swiss Journal of Economics and Statistics (SJES) 150.IV, 261-296.

Feenstra, Robert C., Zhiyuan Li, and Miaojie Yu, 2014, Exports and Credit Constraints under Incomplete Information: Theory and Evidence from China, The Review of Economics and Statistics 96.3, 729-744. 
Gopinath, Gita, Oleg Itskhoki, and Roberto Rigobon, 2010, Currency Choice and Exchange Rate Pass-Through, American Economic Review 100.1, 304-36.

Greenaway, David, Alessandra Guariglia, and Richard Kneller, 2007, Financial factors and exporting decisions, Journal of International Economics 73.2, 377-395.

IGF, 2012, Analyse de lopportunité et des modalités de mise en uvre dun soutien public au financement des crédits export, Rapport N.2012-M-076-01, Inspection Gnrale des Finances.

IGF, 2013, Dispositif de financement public l'exportation, Rapport N.2013-M-082-02, Inspection Générale des Finances.

Imbens, Guido and Jeffrey Wooldridge, 2008, Recent devlopments in the econometrics of program evaluation, NBER Working Papers 14251, National Bureau of Economic Research, Inc.

Ivashina, Victoria, David S. Scharfstein, and Jeremy C. Stein, 2015, Dollar Funding and the Lending Behavior of Global Banks, The Quarterly Journal of Economics 130.3, 12411281.

Khwaja, Asim Ijaz and Atif Mian, 2008, Tracing the impact of bank liquidity shocks: evidence from an emerging market, American Economic Review 98, 1413-1442.

Levchenko, Andrei A, Logan T Lewis, and Linda L Tesar, 2010, The Collapse of International Trade during the 200809 Crisis: In Search of the Smoking Gun, IMF Economic Review $58.2,214-253$.

Lyonnet, Victor, Julien Martin, and Isabelle Mejean, 2016, Invoicing Currency and Financial Hedging, CEPR Discussion Papers 11700, C.E.P.R. Discussion Papers.

Manova, Kalina, 2013, Credit Constraints, Heterogeneous Firms, and International Trade, Review of Economic Studies 80.2, 711-744.

Manova, Kalina, Shang-Jin Wei, and Zhiwei Zhang, 2015, Firm Exports and Multinational Activity Under Credit Constraints, The Review of Economics and Statistics 97.3, 574-588.

Miu, Jason, Asani Sarkar, and Alexander Tepper, 2012, The European Debt Crisis and the Dollar Funding Gap, Liberty Street Economics, Federal Reserve Bank of New York, August 8, 2012. Federal Reserve Bank of New York.

Muûls, Mirabelle, 2015, Exporters, importers and credit constraints, Journal of International Economics 95.2, 333-343.

Niepmann, Friederike and Tim Schmidt-Eisenlohr, Nov. 2015, International Trade Risk and the Role of Banks, International Finance Discussion Papers N.1151.

Paravisini, Daniel, Veronica Rappoport, Philipp Schnabl, and Daniel Wolfenzon, 2015, Dissecting the Effect of Credit Supply on Trade: Evidence from Matched Credit-Export Data, Review of Economic Studies 82.1, 333-359. 
Paravisini, Daniel, Veronica Rappoport, and Philipp Schnabl, 2017, Specialization in Bank Lending: Evidence from Exporting Firms.

Peek, Joe and Eric S Rosengren, 1997, The International Transmission of Financial Shocks: The Case of Japan, American Economic Review 87.4, 495-505.

Schmidt-Eisenlohr, Tim, 2013, Towards a theory of trade finance, Journal of International Economics $91.1,96-112$.

Sushko, Vladyslav, Claudio Borio, Robert Neil McCauley, and Patrick McGuire, 2016, The failure of covered interest parity: FX hedging demand and costly balance sheets. 
Figure 1: French banks' crossborder US Dollars liabilities to financial institutions in the US and worldwide: a major funding shock in the Summer of 2011.

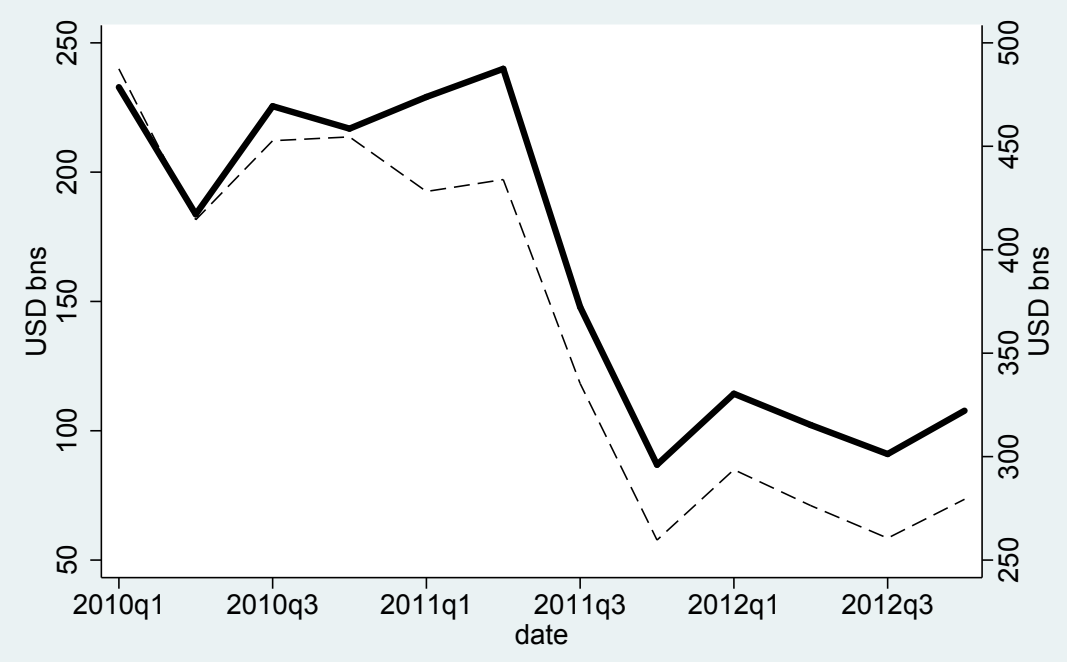

Vis-à-vis US-based fin. instit. (Ihs)
----- Vis-à-vis all non-resident fin. instit. (rhs) 
Figure 2: Foreign dollar funding exposure and exporter size in the US market

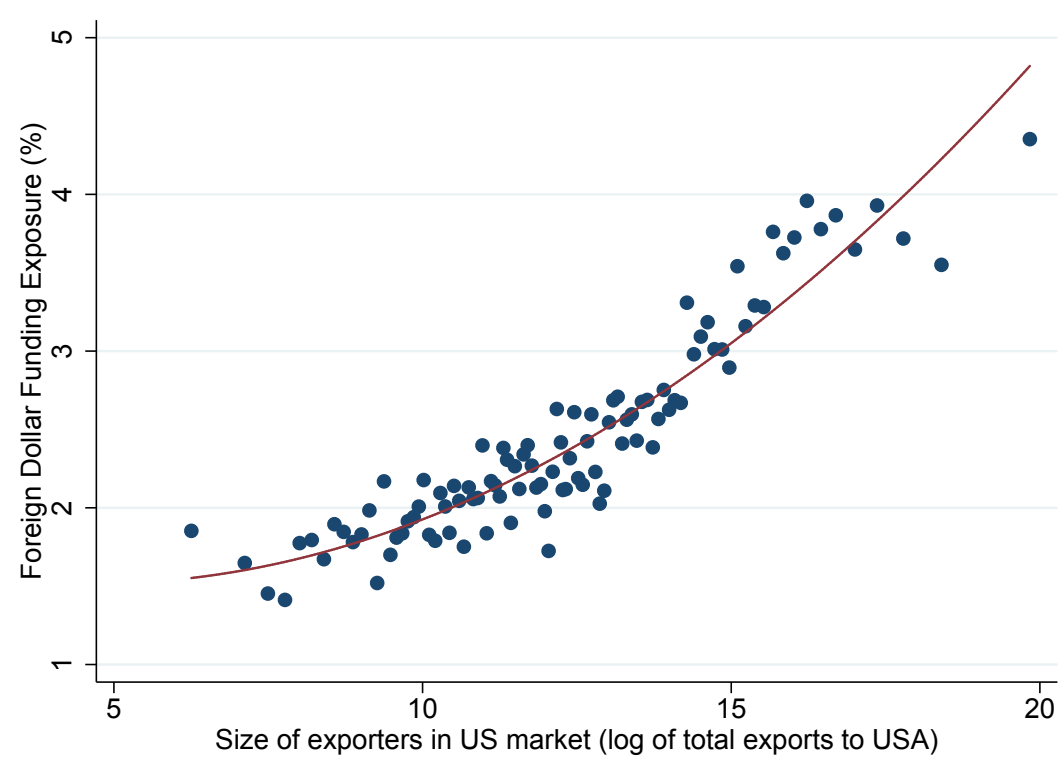


Table 1: Descriptive statistics for the selected banks (22 banks)

\begin{tabular}{|c|c|c|c|c|c|c|}
\hline & mean & p50 & $\mathrm{sd}$ & $\mathrm{p} 25$ & $\mathrm{p} 75$ & p90 \\
\hline \multicolumn{7}{|l|}{ Assets } \\
\hline Total Assets (bns) & 225.75 & 22.52 & 338.24 & 2.83 & 311.22 & 791.22 \\
\hline Loans (/Assets) & 24.23 & 19.69 & 14.33 & 13.63 & 39.75 & 43.08 \\
\hline Interbank Assets (/Assets) & 28.80 & 26.00 & 20.03 & 14.69 & 38.52 & 51.64 \\
\hline \multicolumn{7}{|l|}{ Liabilities } \\
\hline Capital (/Assets) & 5.14 & 4.94 & 2.39 & 2.95 & 6.82 & 8.13 \\
\hline Interbank Liabilities (/Assets) & 26.10 & 22.38 & 18.98 & 12.20 & 39.35 & 44.29 \\
\hline Deposits (/Assets) & 42.55 & 46.26 & 25.13 & 18.92 & 58.91 & 81.56 \\
\hline \multicolumn{7}{|l|}{ Dollar assets/liabilities } \\
\hline Dollar Liab. viz US (/Assets) & 1.07 & 0.06 & 2.31 & 0.00 & 0.47 & 3.75 \\
\hline Dollar Assets viz NFC US (/Assets) & 0.05 & 0.02 & 0.08 & 0.00 & 0.08 & 0.15 \\
\hline Dollar Liab. viz US (Growth) & -53.26 & -29.60 & 185.83 & -97.98 & 0.21 & 204.55 \\
\hline Dollar Assets viz US (Growth) & -6.36 & 5.31 & 45.37 & -26.83 & 28.04 & 43.41 \\
\hline
\end{tabular}

Note. This table presents descriptive statistics for the selected banks in our sample. Bank total assets are expressed in billions of euros. Total assets and credit growth are given as a percentage and are defined in terms of logarithm difference of the corresponding variable. Unless otherwise stated, the other rows refer to ratios of the mentioned balance sheet item to the banks total assets (as a percentage). All balance sheet variables are measured as of June 2011 in terms of a ratio to their total assets and refer to unconsolidated banking group statements. Loans is the ratio of drawn credit to firms to the bank's total assets. Capital is the unweighted Tier 1 capital-to-assets ratio. 
Table 2: Descriptive stat for firms in the sample, continuing exporters to US

\begin{tabular}{|c|c|c|c|c|c|c|}
\hline & $\mathrm{N}$ & mean & sd & p10 & p50 & p90 \\
\hline Exposure to Dollar shock $(\%)_{f, t o}$ & 5,318 & 1.93 & 2.53 & 0.02 & 0.47 & 6.40 \\
\hline Number of banks $_{f, t o}$ & 5,318 & 3.64 & 2.99 & 1.00 & 3.00 & 8.00 \\
\hline ln number of banks $f, t o$ & 5,318 & 1.01 & 0.76 & 0.00 & 1.10 & 2.08 \\
\hline Avg. bank size $f, t o$ & 5,318 & 652.56 & 265.74 & 214.02 & 663.67 & 974.10 \\
\hline ln Avg. bank size $f, t o$ & 5,318 & 6.28 & 0.87 & 5.37 & 6.50 & 6.88 \\
\hline Total exports $_{f, t o}$ & 5,318 & 21,308 & 196026 & 67 & 1,280 & 25,224 \\
\hline In total exports $f, t o$ & 5,318 & 7.17 & 2.30 & 4.21 & 7.16 & 10.14 \\
\hline Theoretical markup $_{f, t o}$ & 5,318 & 1.29 & 1.11 & 1.25 & 1.25 & 1.27 \\
\hline In theoretical markup $f, t o$ & 5,318 & 0.24 & 0.09 & 0.22 & 0.22 & 0.24 \\
\hline $\mathrm{Nb}$ products & 5,318 & 1.95 & 3.35 & 1.00 & 1.00 & 3.00 \\
\hline Total employment $_{f, t 0}$ & 3,656 & 197.80 & 743.55 & 7.00 & 41.00 & 342.00 \\
\hline In total employment ${ }_{f, t 0}$ & 3,644 & 3.82 & 1.57 & 1.95 & 3.71 & 5.83 \\
\hline Link with US banks $_{f, t o}$ & 5,318 & 0.11 & 0.31 & 0.00 & 0.00 & 1.00 \\
\hline Share total credit from US banks $(\%)_{f, t o}$ & 400 & 18.48 & 25.09 & 0.99 & 6.33 & 59.01 \\
\hline
\end{tabular}

Note. $\overline{\overline{\text { Total number of firms exporting in t0: 8,826. Total number of continuing exporters between T0 and T1 }}}$ with non-missing growth rate of exports: 5,318. Growth rates are computed from July 2010-June 2011 to July 2011-June 2012 and given as a percentage. Share total credit from US banks is the share of total bank credit obtained by French exporters from US banks, for those borrowing from US banks. 
Table 3: Differences between the sample of "treated" and "control firms" - Treated firms: upper $50 \%$ of firm exposure distribution; Control: lower $50 \%$

\begin{tabular}{lcccc}
\hline \hline $\begin{array}{l}\text { Sample } \\
\text { \$-shock } \\
\text { Statistic }\end{array}$ & $\begin{array}{c}\text { "Treated" } \\
\text { (above median) } \\
\text { Mean }\end{array}$ & $\begin{array}{c}\text { "Non-treated" } \\
\text { (below median) } \\
\text { Mean }\end{array}$ & Norm. Diff. & $\begin{array}{c}\text { Norm. Diff. } \\
\text { (using weights) }\end{array}$ \\
\hline Bank-firm controls & & & & \\
ln number of banks $f$, to & 1.34 & 1.01 & 0.41 & 0.10 \\
ln Avg. bank size $f, t o$ & 6.59 & 6.46 & 0.40 & 0.07 \\
Firm controls & & & & \\
ln total exports $f, t o$ & & & 0.71 & 0.16 \\
ln theoretical markup $f, t o$ & 0.24 & 0.23 & 0.06 & -0.01 \\
& & & & 7,242 \\
\hline Observations & 5,084 & 5,088 & 10,172 & 7.24 \\
\hline
\end{tabular}

Note. The treated group consists of firms with higher-than-median Firm Exposure, firms in the control group have lower-than-median Firm Exposure. The normalized difference (Imbens and Wooldridge 2009) is defined as the difference between the means of the treated and of the control group, normalized by the square root of the sum of the variances. In the last column, the normalized difference uses the same weights as those in the Propensity Score Weighting. The sample used in the last column is trimmed so that the propensity score ranges from 0.1 to 0.9 . 
Table 4: Currency mismatch by sector

\begin{tabular}{lccccc}
\hline \hline & Number of firms & mean & p25 & p50 & p75 \\
\hline & 1,807 & 2 & 2 & 2 & 2 \\
Foodstuffs & 75 & 1.9 & 2 & 2 & 2 \\
Raw Hides, Skins, Leather, & 348 & 1.9 & 2 & 2 & 2 \\
Textiles & 27 & 1.9 & 2 & 2 & 2 \\
Footwear / Headgears & 155 & 1.9 & 1.9 & 2 & 2 \\
Wood \& Wood Products & 71 & 1.8 & 2 & 2 & 2 \\
Animal / Animal Products & 4 & 1.8 & 1.7 & 1.8 & 1.9 \\
Railway & 93 & 1.8 & 1.9 & 2 & 2 \\
Vegetable Products & 332 & 1.8 & 1.8 & 2 & 2 \\
Metals & 163 & 1.7 & 1.8 & 2 & 2 \\
Stone / Glass & 94 & 1.7 & 1.7 & 2 & 2 \\
Vehicles & 387 & 1.7 & 1.5 & 2 & 2 \\
Chemicals & 228 & 1.6 & 1.4 & 2 & 2 \\
Plastics / Rubbers & 544 & 1.6 & 1.4 & 1.9 & 2 \\
Nuclear reactors & 589 & 1.6 & 1.4 & 1.9 & 2 \\
Miscellaneous & 20 & 1.5 & 0.8 & 2 & 2 \\
Mineral Products & 304 & 1.5 & 1.1 & 1.7 & 2 \\
Electrical machinery & 6 & 1.4 & 0.5 & 1.8 & 2 \\
Ships & 71 & 1.4 & 0.9 & 1.6 & 1.9 \\
Aircraft & & & & & \\
& 5,318 & 1.8 & 1.9 & 2 & 2 \\
\hline Total & & & & & \\
\hline \hline
\end{tabular}

Note. Currency mismatch by firm is defined by the normalized absolute difference between exports and imports from the United States, using the following formula: Mismatch $h_{f, t 0}=\frac{\left|v_{f, u s, t 0}-m_{f, u s, t 0}\right|}{0.5^{*}\left(v_{f, u s, t 0}+m_{f, u s, t 0}\right)}$. Sector-level statistics are obtained by computing averages, standard deviations etc. of firm-level mismatch measurements by sector. 
Table 5: Impact of bank-level exposure to the US dollar funding shock on credit received by exporters

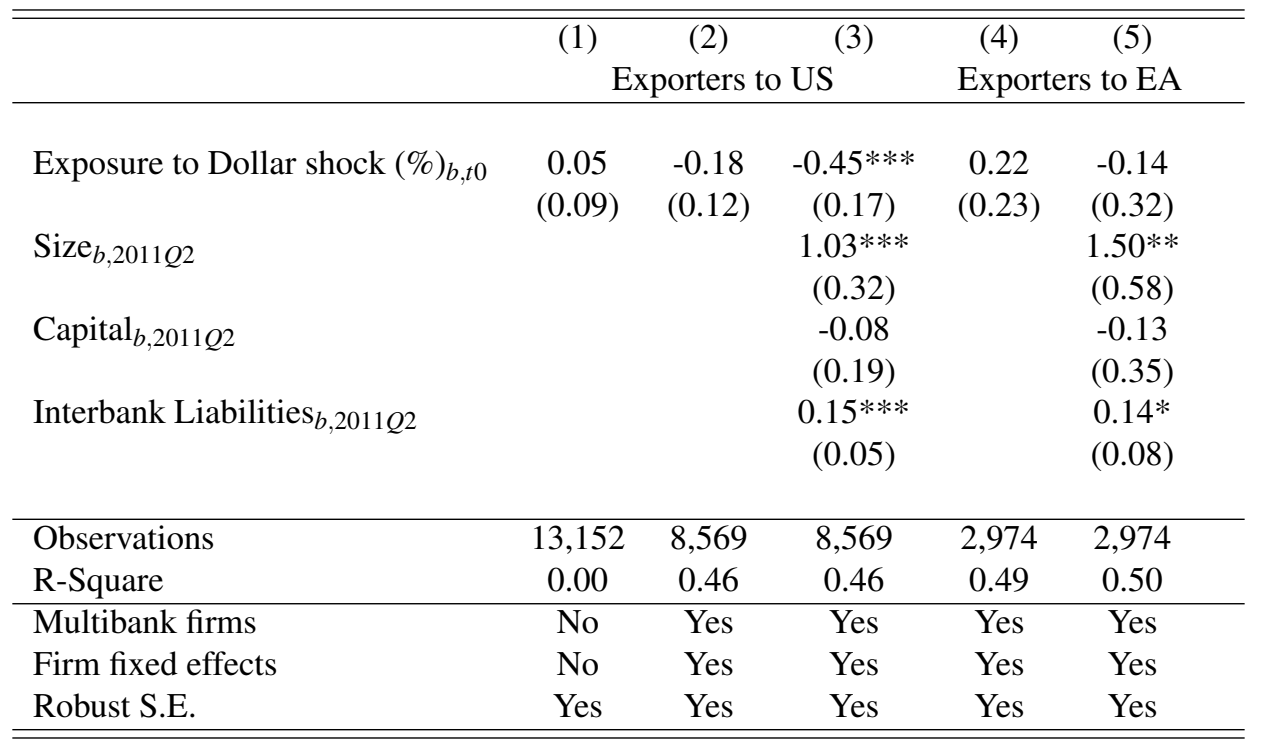

Note. OLS regressions. The dependent variable is the growth rate of total credit from a given bank to a given firm between the period prior to the shock and the shock period. It is computed as the log difference of the variable over the two periods. Significance levels: ${ }^{*} 10 \%,{ }^{*} 5 \%,{ }^{* * *} 1 \%$. Robust standard errors in parentheses. Standard errors estimated with clusters at the bank level are smaller than the robust standard errors, because of the relatively small number of banks. 
Table 6: Firm-level exposure to the US dollar funding shock and relative exports growth to the US.

\begin{tabular}{|c|c|c|c|c|c|}
\hline & $\begin{array}{c}(1) \\
\Delta \ln \widetilde{v}_{f p, u s, t 1}\end{array}$ & $\begin{array}{c}(2) \\
\Delta \ln \widetilde{v}_{f p, u s, t 1}\end{array}$ & $\begin{array}{c}(3) \\
\Delta \ln \widetilde{v}_{f p, u s, t 1}\end{array}$ & $\begin{array}{c}(4) \\
\Delta \ln \widetilde{v}_{f p, u s, t 1}\end{array}$ & $\begin{array}{c}(5) \\
\Delta \ln \widetilde{v}_{f p, u s, t 1}\end{array}$ \\
\hline Exposure to Dollar shock $(\%)_{f, t o}$ & $\begin{array}{c}-0.79^{* *} \\
(0.40)\end{array}$ & $\begin{array}{c}-1.17^{* * *} \\
(0.43)\end{array}$ & $\begin{array}{c}-1.23^{* *} \\
(0.49)\end{array}$ & $\begin{array}{c}-1.27^{* *} \\
(0.56)\end{array}$ & $\begin{array}{c}-1.33^{* *} \\
(0.57)\end{array}$ \\
\hline ln Avg. bank size ${ }_{f, t o}$ & & $\begin{array}{l}2.52^{* *} \\
(1.08)\end{array}$ & $\begin{array}{l}2.61^{* *} \\
(1.20)\end{array}$ & $\begin{array}{c}1.50 \\
(1.22)\end{array}$ & $\begin{array}{c}1.55 \\
(1.20)\end{array}$ \\
\hline ln number of banks $f, t o$ & & & $\begin{array}{c}0.39 \\
(1.69)\end{array}$ & $\begin{array}{l}-1.02 \\
(1.86)\end{array}$ & $\begin{array}{l}-0.99 \\
(1.86)\end{array}$ \\
\hline ln total exports $f, t o$ & & & $\begin{array}{c}0.27 \\
(0.68)\end{array}$ & $\begin{array}{l}-0.35 \\
(0.89)\end{array}$ & $\begin{array}{l}-0.37 \\
(0.90)\end{array}$ \\
\hline In theoretical markup $f, t o$ & & & $\begin{array}{l}-5.33 \\
(7.52)\end{array}$ & $\begin{array}{l}-2.05 \\
(9.91)\end{array}$ & $\begin{array}{l}-1.89 \\
(9.95)\end{array}$ \\
\hline In total employment ${ }_{f, t 0}$ & & & & $\begin{array}{c}0.41 \\
(1.23)\end{array}$ & $\begin{array}{c}0.40 \\
(1.23)\end{array}$ \\
\hline Banks' dollar receivables $_{f, t o}$ & & & & & $\begin{array}{c}7.89 \\
(21.53)\end{array}$ \\
\hline HS4 Product FE & Yes & Yes & Yes & Yes & Yes \\
\hline Firm-level clustering of SE & Yes & Yes & Yes & Yes & Yes \\
\hline $\mathrm{R}^{2}$ & 0.07 & 0.07 & 0.07 & 0.08 & 0.08 \\
\hline Obs. & 10,172 & 10,172 & 10,172 & 7,726 & 7,726 \\
\hline
\end{tabular}

Note. OLS regressions. The dependent variable is the difference between the growth rate of exports of firm $f$ for product $p$ to the United States and the growth rate of exports to the average destination of the firm, between the period prior to the US dollar funding shock and the shock period. Significance levels: ${ }^{*} 10 \%,{ }^{* *} 5 \%,{ }^{* * *} 1 \%$. Standard errors in parentheses clustered at the firm level. Harmonized System 4-digit sector dummies included. 
Table 7: Firm-level exposure to the US dollar funding shock and relative exports growth to the US: non-linear impact

\begin{tabular}{|c|c|c|c|c|c|}
\hline & $\begin{array}{c}(1) \\
\Delta \ln \widetilde{v}_{f p, u s, t 1}\end{array}$ & $\begin{array}{c}(2) \\
\Delta \ln \widetilde{v}_{f p, u s, t 1}\end{array}$ & $\begin{array}{c}(3) \\
\Delta \ln \widetilde{v}_{f p, u s, t 1}\end{array}$ & $\begin{array}{c}(4) \\
\Delta \ln \widetilde{v}_{f p, u s, t 1}\end{array}$ & $\begin{array}{c}(5) \\
\Delta \ln \widetilde{v}_{f p, u s, t 1}\end{array}$ \\
\hline Dollar exposure dummy, 2nd third $f, t o$ & $\begin{array}{l}-0.96 \\
(2.72)\end{array}$ & $\begin{array}{l}-2.54 \\
(2.80)\end{array}$ & $\begin{array}{l}-3.87 \\
(3.19)\end{array}$ & $\begin{array}{l}-5.69 \\
(3.51)\end{array}$ & $\begin{array}{l}-6.65^{*} \\
(3.71)\end{array}$ \\
\hline Dollar exposure dummy, 3 rd third $f, t o$ & $\begin{array}{l}-4.24 \\
(2.77)\end{array}$ & $\begin{array}{l}-6.70^{* *} \\
(2.94)\end{array}$ & $\begin{array}{l}-7.51^{* *} \\
(2.94)\end{array}$ & $\begin{array}{c}-9.60^{* * *} \\
(3.47)\end{array}$ & $\begin{array}{c}-11.16^{* * *} \\
(3.71)\end{array}$ \\
\hline ln Avg. bank size $f, t o$ & & $\begin{array}{l}2.44^{* *} \\
(1.06)\end{array}$ & $\begin{array}{l}2.61^{* *} \\
(1.14)\end{array}$ & $\begin{array}{c}1.90 \\
(1.24)\end{array}$ & $\begin{array}{l}2.15^{*} \\
(1.22)\end{array}$ \\
\hline ln number of banks $f, t o$ & & & $\begin{array}{c}1.18 \\
(1.80)\end{array}$ & $\begin{array}{c}0.08 \\
(1.99)\end{array}$ & $\begin{array}{c}0.31 \\
(2.02)\end{array}$ \\
\hline ln total exports $f, t o$ & & & $\begin{array}{c}0.24 \\
(0.63)\end{array}$ & $\begin{array}{l}-0.28 \\
(0.89)\end{array}$ & $\begin{array}{l}-0.31 \\
(0.89)\end{array}$ \\
\hline $\ln$ theoretical markup $f, t o$ & & & $\begin{array}{l}-6.15 \\
(7.67)\end{array}$ & $\begin{array}{l}-3.05 \\
(10.05)\end{array}$ & $\begin{array}{l}-2.74 \\
(10.05)\end{array}$ \\
\hline ln total employment $f_{f, t}$ & & & & $\begin{array}{c}0.42 \\
(1.22)\end{array}$ & $\begin{array}{c}0.40 \\
(1.22)\end{array}$ \\
\hline Banks' dollar receivables $_{f, t o}$ & & & & & $\begin{array}{c}20.89 \\
(22.64)\end{array}$ \\
\hline HS4 Product FE & Yes & Yes & Yes & Yes & Yes \\
\hline Firm-level clustering of SE & Yes & Yes & Yes & Yes & Yes \\
\hline $\mathrm{R}^{2}$ & 0.07 & 0.07 & 0.07 & 0.08 & 0.08 \\
\hline Obs. & 10,172 & 10,172 & 10,172 & 7,726 & 7,726 \\
\hline
\end{tabular}

Note. OLS regressions. The dependent variable is the difference between the growth rate of exports of firm $f$ for product $p$ to the United States and the growth rate of exports to the average destination of the firm, between the period prior to the US dollar funding shock and the shock period. Significance levels: ${ }^{*} 10 \%,{ }^{* *} 5 \%,{ }^{* * *} 1 \%$. Standard errors in parentheses clustered at the firm level. Harmonized System 4-digit sector dummies included. 
Table 8: Firm exposure to the US dollar funding shock and survival probability

\begin{tabular}{|c|c|c|c|c|}
\hline & $\begin{array}{c}\text { (1) } \\
\text { Survival }_{f p, u s, t 1}\end{array}$ & $\begin{array}{c}\text { (2) } \\
\text { Survival }_{f p, u s, t 1}\end{array}$ & $\begin{array}{c}\text { (3) } \\
\text { Survival }_{f p, u s, t 1}\end{array}$ & $\begin{array}{c}\text { (4) } \\
\text { Survival }_{f p, u s, t 1}\end{array}$ \\
\hline Exposure to Dollar shock $(\%)_{f, t o}$ & $\begin{array}{c}-0.68^{* * *} \\
(0.18)\end{array}$ & $\begin{array}{c}-0.48^{* *} \\
(0.20)\end{array}$ & $\begin{array}{c}-0.80^{* * *} \\
(0.20)\end{array}$ & $\begin{array}{c}-0.57^{* * *} \\
(0.21)\end{array}$ \\
\hline ln Avg. bank size ${ }_{f, t o}$ & $\begin{array}{l}0.01^{* *} \\
(0.01)\end{array}$ & $\begin{array}{l}0.01^{*} \\
(0.01)\end{array}$ & $\begin{array}{c}0.01^{* * *} \\
(0.01)\end{array}$ & $\begin{array}{l}0.01^{* *} \\
(0.01)\end{array}$ \\
\hline ln number of banks $f, t o$ & $\begin{array}{c}-0.02^{* *} \\
(0.01)\end{array}$ & $\begin{array}{c}-0.02^{* *} \\
(0.01)\end{array}$ & $\begin{array}{l}-0.01^{*} \\
(0.01)\end{array}$ & $\begin{array}{c}-0.02^{* *} \\
(0.01)\end{array}$ \\
\hline ln total exports $f, t o$ & $\begin{array}{c}0.04^{* * *} \\
(0.00)\end{array}$ & $\begin{array}{c}0.04^{* * *} \\
(0.00)\end{array}$ & $\begin{array}{c}0.04^{* * *} \\
(0.00)\end{array}$ & $\begin{array}{c}0.05^{* * *} \\
(0.00)\end{array}$ \\
\hline In theoretical markup $f, t o$ & $\begin{array}{c}0.34^{* * *} \\
(0.06)\end{array}$ & $\begin{array}{c}0.33^{* * *} \\
(0.06)\end{array}$ & $\begin{array}{c}0.84^{* * *} \\
(0.26)\end{array}$ & $\begin{array}{c}0.83^{* * *} \\
(0.26)\end{array}$ \\
\hline Banks' dollar receivables $_{f, t o}$ & & $\begin{array}{c}-22.36^{* * *} \\
(6.77)\end{array}$ & & $\begin{array}{c}-26.57^{* * *} \\
(7.00)\end{array}$ \\
\hline HS4 Product FE & Yes & Yes & No & No \\
\hline HS2 Product FE & No & No & Yes & Yes \\
\hline Estimation & OLS & OLS & Probit & Probit \\
\hline Firm-level clustering of SE & Yes & Yes & Yes & Yes \\
\hline Obs. & 19,912 & 19,912 & 20,053 & 20,053 \\
\hline
\end{tabular}

Note. The dependent variable is a dummy variable equal to 1 when product $p$ continues being exported by firm $f$ to the United States during the period of the US dollar funding shock, and zero otherwise. Significance levels: ${ }^{*} 10 \%,{ }^{*} 5 \%,{ }^{* * *} 1 \%$. Standard errors in parentheses clustered at the firm level. Harmonized System 4-digit sector dummies included. Estimators used : Linear probability model in columns (1) and (2); probit in column (3)-(4) with marginal effects reported (at sample mean). 
Table 9: Firm-level exposure to the US dollar funding shock and relative exports growth to the US over June 2010-June 2011: placebo regression.

\begin{tabular}{|c|c|c|c|c|c|}
\hline & $\overline{(1)}$ & (2) & (3) & (4) & 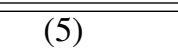 \\
\hline & \multicolumn{5}{|c|}{ Export growth one period before the shock $\left(\Delta \ln \widetilde{v}_{f p, u s, t 0}\right)$} \\
\hline Exposure to Dollar shock $(\%)_{f, t o}$ & $\begin{array}{c}-0.48 \\
(0.43)\end{array}$ & $\begin{array}{l}-0.63 \\
(0.46)\end{array}$ & $\begin{array}{l}-0.52 \\
(0.49)\end{array}$ & $\begin{array}{l}-0.12 \\
(0.60)\end{array}$ & $\begin{array}{l}-0.01 \\
(0.62)\end{array}$ \\
\hline ln number of banks $f, t o$ & & $\begin{array}{c}0.79 \\
(1.56)\end{array}$ & $\begin{array}{c}1.37 \\
(1.76)\end{array}$ & $\begin{array}{c}1.59 \\
(2.12)\end{array}$ & $\begin{array}{c}1.51 \\
(2.13)\end{array}$ \\
\hline ln Avg. bank size ${ }_{f, t o}$ & & $\begin{array}{c}1.06 \\
(1.25)\end{array}$ & $\begin{array}{c}0.88 \\
(1.30)\end{array}$ & $\begin{array}{c}0.69 \\
(1.51)\end{array}$ & $\begin{array}{c}0.58 \\
(1.50)\end{array}$ \\
\hline ln total exports $f, t o$ & & & $\begin{array}{l}-0.57 \\
(0.51)\end{array}$ & $\begin{array}{l}-0.86 \\
(0.84)\end{array}$ & $\begin{array}{l}-0.83 \\
(0.84)\end{array}$ \\
\hline In theoretical markup $f, t o$ & & & $\begin{array}{c}17.86^{*} \\
(10.36)\end{array}$ & $\begin{array}{c}18.30 \\
(12.02)\end{array}$ & $\begin{array}{c}17.90 \\
(12.03)\end{array}$ \\
\hline In total employment ${ }_{f, t 0}$ & & & & $\begin{array}{l}-0.43 \\
(1.27)\end{array}$ & $\begin{array}{c}-0.40 \\
(1.28)\end{array}$ \\
\hline Banks' dollar receivables $_{f, t o}$ & & & & & $\begin{array}{l}-14.61 \\
(22.75)\end{array}$ \\
\hline HS4 Product FE & Yes & Yes & Yes & Yes & Yes \\
\hline Firm-level clustering of SE & Yes & Yes & Yes & Yes & Yes \\
\hline $\mathrm{R}^{2}$ & 0.07 & 0.07 & 0.07 & 0.09 & 0.09 \\
\hline Obs. & 10,267 & 10,267 & 10,267 & 7,421 & 7,421 \\
\hline
\end{tabular}

Note. OLS regressions. The dependent variable is the difference between the growth rate of exports of firm $f$ for product $p$ to the United States and the growth rate of exports to the average destination of the firm, between period T-1 (2 years ahead of the US dollar funding shock) and period T0 (period prior to the US dollar funding shock). Significance levels: ${ }^{*} 10 \%,{ }^{* *} 5 \%,{ }^{* * *} 1 \%$. Standard errors in parentheses clustered at the firm level. Harmonized System 4-digit sector dummies included. 
Table 10: Firm exposure to the US dollar funding shock in June 2011 and relative exports growth to the US: WLS using propensity scores.

\begin{tabular}{|c|c|c|c|c|c|}
\hline & $\begin{array}{c}(1) \\
\Delta \ln \widetilde{v}_{f p, u s, t 1}\end{array}$ & $\begin{array}{c}(2) \\
\Delta \ln \widetilde{v}_{f p, u s, t 1}\end{array}$ & $\begin{array}{c}(3) \\
\Delta \ln \widetilde{v}_{f p, u s, t 1}\end{array}$ & $\begin{array}{c}(4) \\
\Delta \ln \widetilde{v}_{f p, u s, t 1}\end{array}$ & $\begin{array}{c}(5) \\
\Delta \ln \widetilde{v}_{f p, u s, t 1}\end{array}$ \\
\hline Exposure to Dollar shock (\%) & $\begin{array}{c}-1.46^{* * *} \\
(0.53)\end{array}$ & $\begin{array}{c}-1.52^{* * *} \\
(0.57)\end{array}$ & $\begin{array}{c}-1.46^{* *} \\
(0.59)\end{array}$ & $\begin{array}{c}-1.74^{* *} \\
(0.71)\end{array}$ & $\begin{array}{l}-1.44^{*} \\
(0.83)\end{array}$ \\
\hline ln Avg. bank size $f, t o$ & & $\begin{array}{c}2.52 \\
(5.05)\end{array}$ & $\begin{array}{c}4.55 \\
(5.74)\end{array}$ & $\begin{array}{c}4.81 \\
(6.19)\end{array}$ & $\begin{array}{c}4.31 \\
(6.29)\end{array}$ \\
\hline $\ln$ number of banks $f, t o$ & & & $\begin{array}{c}2.77 \\
(1.94)\end{array}$ & $\begin{array}{c}1.53 \\
(2.29)\end{array}$ & $\begin{array}{c}1.65 \\
(2.28)\end{array}$ \\
\hline $\ln$ total exports $f, t o$ & & & $\begin{array}{c}0.26 \\
(0.75)\end{array}$ & $\begin{array}{c}0.54 \\
(1.22)\end{array}$ & $\begin{array}{c}0.57 \\
(1.22)\end{array}$ \\
\hline ln theoretical markup $f, t o$ & & & $\begin{array}{c}3.52 \\
(13.87)\end{array}$ & $\begin{array}{c}7.35 \\
(22.36)\end{array}$ & $\begin{array}{c}6.93 \\
(22.39)\end{array}$ \\
\hline ln total employment $f_{f, t 0}$ & & & & $\begin{array}{c}-0.27 \\
(1.60)\end{array}$ & $\begin{array}{l}-0.21 \\
(1.60)\end{array}$ \\
\hline Banks' dollar receivables $_{f, t o}$ & & & & & $\begin{array}{l}-23.08 \\
(32.98)\end{array}$ \\
\hline HS4 Product FE & Yes & Yes & Yes & Yes & Yes \\
\hline Firm-level clustering of SE & Yes & Yes & Yes & Yes & Yes \\
\hline 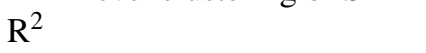 & 0.11 & 0.11 & 0.11 & 0.13 & 0.13 \\
\hline Obs. & 7,242 & 7,242 & 7,242 & 5,548 & 5,548 \\
\hline
\end{tabular}

Note. Weighted least square estimation using propensity scores as weights, following as in Imbens and Wooldridge (2009). The dependent variable is the difference between the growth rate of exports of firm $f$ for product $p$ to the United States and the growth rate of exports to the average destination of the firm, between the period prior to the US dollar funding shock and the shock period. Sample restricted to firms with a propensity score above 0.1 and below 0.9. Significance levels: ${ }^{*} 10 \%,{ }^{* *} 5 \%,{ }^{* * *} 1 \%$. Standard errors in parentheses clustered at the firm level. Harmonized System 4-digit sector dummies included. Propensity score estimated using a logit regression. 
Table 11: Firm exposure to the US dollar funding shock in June 2011 and relative exports growth to the US: non-Europe OECD countries as a reference group

\begin{tabular}{|c|c|c|c|c|c|}
\hline & $\begin{array}{c}(1) \\
\Delta \ln \widetilde{v}_{f p, u s, t 1}\end{array}$ & $\begin{array}{c}(2) \\
\Delta \ln \widetilde{v}_{f p, u s, t 1}\end{array}$ & $\begin{array}{c}(3) \\
\Delta \ln \widetilde{v}_{f p, u s, t 1}\end{array}$ & $\begin{array}{c}(4) \\
\Delta \ln \widetilde{v}_{f p, u s, t 1}\end{array}$ & $\begin{array}{c}(5) \\
\Delta \ln \widetilde{v}_{f p, u s, t 1}\end{array}$ \\
\hline Exposure to Dollar shock $(\%)_{f, t o}$ & $\begin{array}{c}-1.52^{* *} \\
(0.75)\end{array}$ & $\begin{array}{c}-2.48^{* * *} \\
(0.81)\end{array}$ & $\begin{array}{c}-2.42^{* * *} \\
(0.87)\end{array}$ & $\begin{array}{c}-2.99^{* * *} \\
(0.96)\end{array}$ & $\begin{array}{c}-3.07^{* * *} \\
(0.99)\end{array}$ \\
\hline ln number of banks $f, t o$ & & $\begin{array}{l}-2.04 \\
(2.70)\end{array}$ & $\begin{array}{l}-1.80 \\
(2.97)\end{array}$ & $\begin{array}{l}-5.65 \\
(3.49)\end{array}$ & $\begin{array}{l}-5.60 \\
(3.48)\end{array}$ \\
\hline ln Avg. bank size $f, t o$ & & $\begin{array}{c}5.77^{* * *} \\
(1.90)\end{array}$ & $\begin{array}{c}5.65^{* * *} \\
(2.06)\end{array}$ & $\begin{array}{l}4.13^{*} \\
(2.11)\end{array}$ & $\begin{array}{l}4.18^{* *} \\
(2.11)\end{array}$ \\
\hline $\ln$ total exports ${ }_{f, t o}$ & & & $\begin{array}{l}-0.32 \\
(1.15)\end{array}$ & $\begin{array}{l}-2.24 \\
(2.00)\end{array}$ & $\begin{array}{l}-2.25 \\
(2.00)\end{array}$ \\
\hline In theoretical markup $f, t o$ & & & $\begin{array}{c}9.35 \\
(10.28)\end{array}$ & $\begin{array}{c}12.65 \\
(10.88)\end{array}$ & $\begin{array}{c}12.79 \\
(10.89)\end{array}$ \\
\hline In total employment $f_{f, t 0}$ & & & & $\begin{array}{c}1.91 \\
(2.51)\end{array}$ & $\begin{array}{c}1.89 \\
(2.51)\end{array}$ \\
\hline Banks' dollar receivables $_{f, t o}$ & & & & & $\begin{array}{c}12.73 \\
(36.07)\end{array}$ \\
\hline HS4 Product FE & Yes & Yes & Yes & Yes & Yes \\
\hline Firm-level clustering of SE & Yes & Yes & Yes & Yes & Yes \\
\hline $\mathrm{R}^{2}$ & 0.08 & 0.08 & 0.08 & 0.09 & 0.09 \\
\hline Obs. & 7,140 & 7,140 & 7,140 & 5,731 & 5,731 \\
\hline
\end{tabular}

Note. OLS regressions. The dependent variable is the difference between the growth rate of exports of firm $f$ for product $p$ to the United States and the average growth rate of exports to a composite destination composed of remote OECD destinations excluding North America (Australia, Chile, Israel, Japan, Korea and New-Zealand), between the period prior to the US dollar funding shock and the shock period. Significance levels: ${ }^{*} 10 \%,{ }^{* *} 5 \%$, *** $1 \%$. Standard errors in parentheses clustered at the firm level. Harmonized System 4-digit sector dummies included. 
Table 12: Impact of Firm exposure to the dollar funding cost on firm-level relative imports from the United States

\begin{tabular}{lcccc}
\hline \hline & $(1)$ & $(2)$ & $(3)$ & $(4)$ \\
& $\Delta \ln \widetilde{m}_{f p, u s, t 1}$ & $\Delta \ln \widetilde{m}_{f p, u s, t 1}$ & $\Delta \ln \widetilde{m}_{f p, u s, t 1}$ & $\Delta \ln \tilde{m}_{f p, u s, t 1}$ \\
\hline Exposure to Dollar shock (\%) & 0.15 & 0.19 & 0.09 & 0.14 \\
& $(0.34)$ & $(0.38)$ & $(0.40)$ & $(0.46)$ \\
ln number of banks ${ }_{f, t o}$ & & 0.23 & -0.05 & -1.23 \\
& & $(1.14)$ & $(1.18)$ & $(1.42)$ \\
ln Avg. bank size ${ }_{f, t o}$ & & -0.23 & -0.15 & -0.39 \\
& & $(0.90)$ & $(0.91)$ & $(1.02)$ \\
ln Total imports & & & 0.50 & 0.49 \\
& & & $(0.52)$ & $(0.67)$ \\
ln Total employment & & & & -0.06 \\
& & & & $(0.72)$ \\
\hline Observations & 13,671 & 13,671 & 13,402 & 10,877 \\
R-square & 0.06 & 0.06 & 0.06 & 0.06 \\
HS4 product fixed effects & Yes & Yes & Yes & Yes \\
Firm-level clustering of S.E. & Yes & Yes & Yes & Yes \\
\hline \hline
\end{tabular}

Note. OLS regressions. The dependent variable is the difference between the growth rate of imports of firm $f$ for product $p$ from the United States and the growth rate of imports from the average destination of the firm, between the period prior to the US dollar funding shock and the shock period. Significance levels: ${ }^{*} 10 \%,{ }^{* *} 5 \%,{ }^{* * *} 1 \%$. Standard errors in parentheses clustered at the firm level. Harmonized System 4-digit sector dummies included. 
Table 13: Impact of Firm exposure to the dollar funding cost on firm-level relative exports from the United States : interactions with import status and total import value

\begin{tabular}{|c|c|c|c|c|}
\hline & $\begin{array}{c}(1) \\
\Delta \ln \widetilde{v}_{f p, u s, t 1}\end{array}$ & $\begin{array}{c}(2) \\
\Delta \ln \widetilde{v}_{f p, u s, t 1}\end{array}$ & $\begin{array}{c}(3) \\
\Delta \ln \widetilde{v}_{f p, u s, t 1}\end{array}$ & $\begin{array}{c}(4) \\
\Delta \ln \widetilde{v}_{f p, u s, t 1}\end{array}$ \\
\hline Exposure to Dollar shock (\%) & $\begin{array}{l}-1.19 \\
(0.83)\end{array}$ & $\begin{array}{l}-4.92 * \\
(2.58)\end{array}$ & $\begin{array}{c}-1.42 * * \\
(0.61)\end{array}$ & $\begin{array}{c}-2.81 * * \\
(1.20)\end{array}$ \\
\hline Exposure $\times \operatorname{import~status~}_{f, t o}$ & $\begin{array}{l}-0.07 \\
(0.94)\end{array}$ & & & \\
\hline Import status $_{f, t o}$ & $\begin{array}{c}5.53 \\
(3.72)\end{array}$ & & & \\
\hline Exposure $\times$ Log total imports $f, t o$ & & $\begin{array}{c}0.28 \\
(0.21)\end{array}$ & & \\
\hline $\log _{\text {total imports }} f, t o$ & & $\begin{array}{l}-1.75 \\
(1.10)\end{array}$ & & \\
\hline Exposure $\times$ import status $\mathrm{US}_{f, t o}$ & & & $\begin{array}{c}0.30 \\
(0.80)\end{array}$ & \\
\hline Import status $\mathrm{US}_{f, t o}$ & & & $\begin{array}{c}1.74 \\
(3.45)\end{array}$ & \\
\hline Exposure $\times$ Log total imports $\mathrm{US}_{f, t o}$ & & & & $\begin{array}{l}0.30^{*} \\
(0.18)\end{array}$ \\
\hline Log total imports $\mathrm{US}_{f, t o}$ & & & & $\begin{array}{c}-2.05^{* *} \\
(1.01)\end{array}$ \\
\hline ln number of banks $f, t o$ & $\begin{array}{c}0.14 \\
(1.72)\end{array}$ & $\begin{array}{c}0.12 \\
(1.93)\end{array}$ & $\begin{array}{c}0.42 \\
(1.70)\end{array}$ & $\begin{array}{l}-0.25 \\
(2.38)\end{array}$ \\
\hline ln Avg. bank size $\mathrm{e}_{f, t o}$ & $\begin{array}{l}2.63^{* *} \\
(1.21)\end{array}$ & $\begin{array}{l}3.28 * * \\
(1.35)\end{array}$ & $\begin{array}{l}2.60 * * \\
(1.21)\end{array}$ & $\begin{array}{c}2.03 \\
(1.77)\end{array}$ \\
\hline ln total exports $f, t o$ & $\begin{array}{c}0.08 \\
(0.71)\end{array}$ & $\begin{array}{c}0.64 \\
(1.03)\end{array}$ & $\begin{array}{c}0.09 \\
(0.70)\end{array}$ & $\begin{array}{c}0.71 \\
(0.98)\end{array}$ \\
\hline In theoretical markup $f, t o$ & $\begin{array}{l}-4.88 \\
(7.55)\end{array}$ & $\begin{array}{l}-4.71 \\
(8.10)\end{array}$ & $\begin{array}{l}-5.66 \\
(7.58) \\
\end{array}$ & $\begin{array}{l}-1.56 \\
(10.46) \\
\end{array}$ \\
\hline Observations & 10,172 & 8,116 & 10,172 & 5,521 \\
\hline $\mathrm{R}$-square & 0.07 & 0.08 & 0.07 & 0.09 \\
\hline HS4 product fixed effects & Yes & Yes & Yes & Yes \\
\hline Firm-level clustering of S.E. & Yes & Yes & Yes & Yes \\
\hline
\end{tabular}

Note. OLS regressions. The dependent variable is the difference between the growth rate of exports of firm $f$ for product $p$ to the United States and the growth rate of exports to the average destination of the firm, between the period prior to the US dollar funding shock and the shock period. Significance levels: ${ }^{*} 10 \%,{ }^{* *} 5 \%,{ }^{* * *} 1 \%$. Standard errors in parentheses clustered at the firm level. Harmonized System 4-digit sector dummies included. The import status of a firm is a dummy variable and the log total imports is continuous. Each variable is measured using information on the twelve months preceding the shock in June 2011. 
Table 14: Impact of Firm exposure to the dollar funding cost and currency mismatch between the firm's imports and exports

\begin{tabular}{|c|c|c|c|c|c|}
\hline & $\begin{array}{c}(1) \\
\Delta \ln \widetilde{v}_{f p, u s, t 1} \\
\text { Low mismatch }\end{array}$ & $\begin{array}{c}(2) \\
\Delta \ln \widetilde{v}_{f p, u s, t 1} \\
\text { High mismatch }\end{array}$ & $\begin{array}{c}(3) \\
\Delta \ln \widetilde{v}_{f p, u s, t 1}\end{array}$ & $\begin{array}{c}\quad(4) \\
\Delta \ln \widetilde{v}_{f p, u s, t 1} \\
\text { Full sample }\end{array}$ & $\begin{array}{c}(5) \\
\Delta \ln \widetilde{v}_{f p, u s, t 1}\end{array}$ \\
\hline Exposure to Dollar shock (\%) & $\begin{array}{l}-0.86 \\
(0.98)\end{array}$ & $\begin{array}{c}-1.84 * * \\
(0.75)\end{array}$ & $\begin{array}{c}0.07 \\
(1.43)\end{array}$ & & \\
\hline$\times$ mismatch $_{f, t 0}$ & & & $\begin{array}{l}-0.86 \\
(0.78)\end{array}$ & & \\
\hline$\times$ Dummy mismatch $\mathrm{T} 1_{f, t 0}$ & & & & $\begin{array}{l}-0.30 \\
(1.00)\end{array}$ & $\begin{array}{c}-0.89 \\
(1.11)\end{array}$ \\
\hline$\times$ Dummy mismatch $\mathrm{T} 2_{f, t 0}$ & & & & $\begin{array}{l}-1.65 \\
(1.01)\end{array}$ & $\begin{array}{l}-2.00^{*} \\
(1.03)\end{array}$ \\
\hline$\times$ Dummy mismatch $\mathrm{T} 3_{f, t 0}$ & & & & $\begin{array}{c}-1.75^{* * *} \\
(0.70)\end{array}$ & $\begin{array}{c}-1.75^{* * *} \\
(0.70)\end{array}$ \\
\hline$\times$ Twoway trade $f p, t o$ & & & & & $\begin{array}{c}1.33 \\
(1.44)\end{array}$ \\
\hline Banks' dollar receivables $_{f, t 0}$ & $\begin{array}{l}59.33^{*} \\
(35.63)\end{array}$ & $\begin{array}{l}-21.31 \\
(30.51)\end{array}$ & $\begin{array}{c}7.42 \\
(21.40)\end{array}$ & $\begin{array}{c}6.57 \\
(21.50)\end{array}$ & $\begin{array}{c}6.76 \\
(21.49)\end{array}$ \\
\hline Observations & 3,320 & 4,192 & 7,746 & 7,746 & 7,746 \\
\hline R-square & 0.11 & 0.12 & 0.08 & 0.08 & 0.08 \\
\hline HS4 product fixed effects & Yes & Yes & Yes & Yes & Yes \\
\hline Firm-level clustering of S.E. & Yes & Yes & Yes & Yes & Yes \\
\hline
\end{tabular}

Note. OLS regressions. The dependent variable is the difference between the growth rate of exports of firm $f$ for product $p$ to the United States and the growth rate of exports to the average destination of the firm, between the period prior to the US dollar funding shock and the shock period. Significance levels: ${ }^{*} 10 \%,{ }^{* *} 5 \%,{ }^{* * *} 1 \%$. Standard errors in parentheses clustered at the firm level. Harmonized System 4-digit sector dummies included. In each estimation, we consider only one single export destination: the United States. The firm's currency mismatch is defined as the absolute value of the difference of its imports from and exports to the US, normalized by half the sum of these exports and imports, ex ante (taking averages over the 12 months before the shock). We sort firms in three groups of equal sizes according to the value of their currency mismatch. Low mismatch firms are below the 33rd percentile, high mismatch firms are above the 66th percentile. 
Table 15: Impact of Firm exposure to the dollar funding shock and firm-level markup

\begin{tabular}{|c|c|c|c|c|c|}
\hline Dollar funding exposure & $\begin{array}{c}(1) \\
\Delta \ln \widetilde{v}_{f p, u s, t 1} \\
\text { Low }\end{array}$ & $\begin{array}{c}(2) \\
\Delta \ln \widetilde{v}_{f p, u s, t 1} \\
\text { Intermediate }\end{array}$ & $\begin{array}{c}(3) \\
\Delta \ln \widetilde{v}_{f p, u s, t 1} \\
\text { High }\end{array}$ & $\begin{array}{c}(4) \\
\Delta \ln \widetilde{v}_{f p, u s, t 1} \\
\text { All ex }\end{array}$ & $\begin{array}{l}\quad(5) \\
\Delta \ln \widetilde{v}_{f p, u s, t 1} \\
\text { osures }\end{array}$ \\
\hline In theoretical markup $f, t o$ & $\begin{array}{l}43.05^{*} \\
(23.80)\end{array}$ & $\begin{array}{c}-14.58 \\
(40.54)\end{array}$ & $\begin{array}{c}-18.41^{* *} \\
(8.40)\end{array}$ & $\begin{array}{l}38.12^{*} \\
(21.20)\end{array}$ & \\
\hline Dollar exposure dummy, 2 nd third ${ }_{f, t o}$ & & & & $\begin{array}{l}11.18 \\
(8.43)\end{array}$ & $\begin{array}{l}-3.28 \\
(3.26)\end{array}$ \\
\hline Exposure $\mathrm{T} 2 \times \ln \operatorname{markup}_{f, t o}$ & & & & $\begin{array}{r}-64.95^{* *} \\
(32.41)\end{array}$ & \\
\hline Exposure T2 $\times$ Market Share $_{f, t o}$ & & & & & $\begin{array}{c}-83.90^{*} \\
(49.05)\end{array}$ \\
\hline Dollar exposure dummy, 3 rd third $f, t o$ & & & & $\begin{array}{c}3.96 \\
(5.88)\end{array}$ & $\begin{array}{c}-6.98^{* *} \\
(2.98)\end{array}$ \\
\hline Exposure $\mathrm{T} 3 \times \ln \operatorname{markup}_{f, t o}$ & & & & $\begin{array}{c}-49.69^{* *} \\
(21.47)\end{array}$ & \\
\hline Exposure T3 $\times$ Market Share $_{f, t o}$ & & & & & $\begin{array}{l}-70.61^{*} \\
(38.84)\end{array}$ \\
\hline Market Share $_{f, t o}$ & & & & & $\begin{array}{c}40.75 \\
(36.97)\end{array}$ \\
\hline ln number of banks $f, t o$ & $\begin{array}{l}5.54^{* *} \\
(2.49)\end{array}$ & $\begin{array}{c}0.45 \\
(3.46)\end{array}$ & $\begin{array}{l}-1.00 \\
(3.27)\end{array}$ & $\begin{array}{c}1.15 \\
(1.80)\end{array}$ & $\begin{array}{c}1.15 \\
(1.80)\end{array}$ \\
\hline ln Avg. bank size ${ }_{f, t o}$ & $\begin{array}{c}2.37^{*} \\
(1.38)\end{array}$ & $\begin{array}{l}-3.90 \\
(4.12)\end{array}$ & $\begin{array}{c}8.97 \\
(6.76)\end{array}$ & $\begin{array}{l}2.80^{* *} \\
(1.16)\end{array}$ & $\begin{array}{l}2.81^{* *} \\
(1.17)\end{array}$ \\
\hline ln total exports $f, t o$ & $\begin{array}{l}-0.03 \\
(0.71)\end{array}$ & $\begin{array}{l}-0.48 \\
(1.19)\end{array}$ & $\begin{array}{c}1.46 \\
(1.38)\end{array}$ & $\begin{array}{c}0.23 \\
(0.63)\end{array}$ & $\begin{array}{c}0.30 \\
(0.65)\end{array}$ \\
\hline HS4 Product FE & Yes & Yes & Yes & Yes & Yes \\
\hline Firm-level clustering of SE & Yes & Yes & Yes & Yes & Yes \\
\hline $\mathrm{R}^{2}$ & 0.11 & 0.16 & 0.11 & 0.07 & 0.07 \\
\hline Obs. & 4,113 & 2,231 & 3,367 & 10,172 & 10,172 \\
\hline
\end{tabular}

Note. OLS regressions. The dependent variable is the difference between the growth rate of exports of firm $f$ for product $p$ to the United States and the growth rate of exports to the average destination of the firm, between the period prior to the US dollar funding shock and the shock period. Significance levels: ${ }^{*} 10 \%,{ }^{* *} 5 \%,{ }^{* * *} 1 \%$. Standard errors in parentheses clustered at the firm level. Harmonized System 4-digit sector dummies included. 


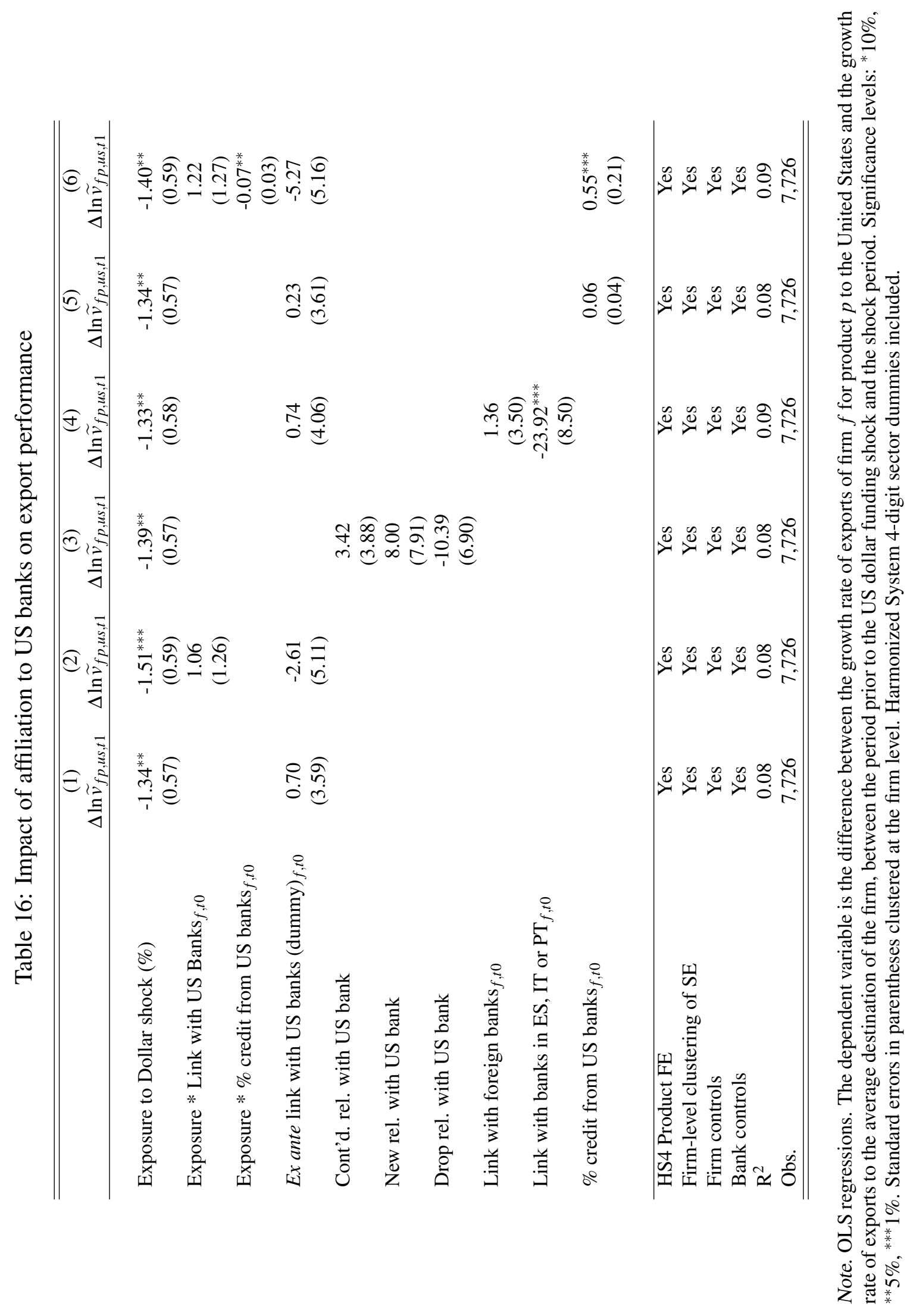


Table 17: Affiliations to US banks during the shock period

\begin{tabular}{|c|c|c|c|c|c|}
\hline Affiliation with US bank & $\begin{array}{c}(1) \\
\text { Change t1/t0 }\end{array}$ & $\begin{array}{c}(2) \\
\text { New }\end{array}$ & $\begin{array}{c}\text { (3) } \\
\text { Drop }\end{array}$ & $\begin{array}{c}\text { (4) } \\
\text { Credit growth } \\
\text { with US bank }\end{array}$ & $\begin{array}{c}\text { (5) } \\
\text { Credit growth } \\
\text { rel. to FR banks }\end{array}$ \\
\hline Exposure to Dollar shock (\%) & $\begin{array}{l}-0.00 \\
(0.00)\end{array}$ & $\begin{array}{c}0.00 \\
(0.00)\end{array}$ & $\begin{array}{c}0.00 \\
(0.00)\end{array}$ & $\begin{array}{c}1.99 \\
(2.08)\end{array}$ & $\begin{array}{l}-0.73 \\
(2.62)\end{array}$ \\
\hline$\%$ credit from US banks ${ }_{f, t 0}$ & $\begin{array}{l}-0.00 \\
(0.00)\end{array}$ & $\begin{array}{l}-0.00 \\
(0.00)\end{array}$ & $\begin{array}{l}-0.00 \\
(0.00)\end{array}$ & $\begin{array}{c}0.06 \\
(0.12)\end{array}$ & $\begin{array}{c}0.08 \\
(0.15)\end{array}$ \\
\hline ln number of banks ${ }_{f, t o}$ & $\begin{array}{c}-0.01^{* *} \\
(0.01)\end{array}$ & $\begin{array}{c}0.01^{* * *} \\
(0.00)\end{array}$ & $\begin{array}{c}0.03^{* * *} \\
(0.00)\end{array}$ & $\begin{array}{c}1.14 \\
(7.54)\end{array}$ & $\begin{array}{l}-2.72 \\
(9.48)\end{array}$ \\
\hline In Avg. bank size $f, t o$ & $\begin{array}{l}0.01^{*} \\
(0.00)\end{array}$ & $\begin{array}{l}-0.00 \\
(0.00)\end{array}$ & $\begin{array}{c}-0.01^{* * *} \\
(0.00)\end{array}$ & $\begin{array}{l}-9.39^{*} \\
(5.04)\end{array}$ & $\begin{array}{l}-3.74 \\
(6.34)\end{array}$ \\
\hline ln total employment ${ }_{f, t 0}$ & $\begin{array}{c}0.00 \\
(0.00)\end{array}$ & $\begin{array}{l}0.00^{* *} \\
(0.00)\end{array}$ & $\begin{array}{l}0.00^{*} \\
(0.00)\end{array}$ & $\begin{array}{l}-0.72 \\
(2.88)\end{array}$ & $\begin{array}{c}0.86 \\
(3.62)\end{array}$ \\
\hline HS2 Product FE & Yes & Yes & Yes & Yes & Yes \\
\hline Firm-level clustering of SE & Yes & Yes & Yes & Yes & Yes \\
\hline $\mathrm{R}^{2}$ & 0.03 & 0.03 & 0.04 & 0.14 & 0.10 \\
\hline Obs. & 3,380 & 3,380 & 3,380 & 305 & 305 \\
\hline
\end{tabular}

Note. OLS regressions. The dependent variable is a dummy variable equal to 1 if the firm is in a relation with a US bank located in France (branch or affiliate) and zero otherwise. Significance levels: ${ }^{*} 10 \%,{ }^{* *} 5 \%,{ }^{* * *} 1 \%$. Standard errors in parentheses clustered at the firm level. Harmonized System 2-digit sector dummies included. 
Table 18: Survey-based evidence on the use of hedging instruments

\begin{tabular}{|c|c|c|c|c|c|}
\hline \multirow{3}{*}{ Dep. var. } & (1) & (2) & 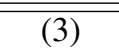 & $\overline{~(4) ~}$ & \multirow[t]{3}{*}{ (5) } \\
\hline & \multirow{2}{*}{\multicolumn{4}{|c|}{$\begin{array}{l}\text { Absolute variation of exports: } \Delta \ln v_{f p, u s, t 1} \\
\text { Use hedging instruments } \\
\text { No } \quad \text { Yes }\end{array}$}} & \\
\hline & & & & & \\
\hline Exposure to Dollar shock $(\%)$ & $\begin{array}{c}3.17 \\
(3.41)\end{array}$ & $\begin{array}{c}-5.07^{* *} \\
(1.99)\end{array}$ & $\begin{array}{c}3.09 \\
(3.00)\end{array}$ & $\begin{array}{c}3.38 \\
(3.07)\end{array}$ & $\begin{array}{c}1.65 \\
(3.24)\end{array}$ \\
\hline Exposure $\times$ Use of Heding $f$ & & & $\begin{array}{c}-8.11^{* *} \\
(3.45)\end{array}$ & $\begin{array}{c}-8.46^{* *} \\
(3.60)\end{array}$ & $\begin{array}{c}-8.37^{* *} \\
(3.95)\end{array}$ \\
\hline Use of Heding $f$ & & & $\begin{array}{c}16.61 \\
(13.00)\end{array}$ & $\begin{array}{c}20.01 \\
(15.96)\end{array}$ & $\begin{array}{c}20.53 \\
(17.54)\end{array}$ \\
\hline ln Avg. bank size $f$, to & $\begin{array}{c}2.91 \\
(8.33)\end{array}$ & $\begin{array}{l}3.49^{*} \\
(1.95)\end{array}$ & $\begin{array}{c}3.39 \\
(2.16)\end{array}$ & $\begin{array}{c}3.02 \\
(2.24)\end{array}$ & $\begin{array}{c}2.15 \\
(2.66)\end{array}$ \\
\hline ln Total exports $\_f, t o$ & & & & $\begin{array}{l}-0.91 \\
(1.72)\end{array}$ & $\begin{array}{l}-2.14 \\
(1.86)\end{array}$ \\
\hline HS2 Product FE & No & No & No & No & Yes \\
\hline Firm-level clustering of SE & Yes & Yes & Yes & Yes & Yes \\
\hline $\mathrm{R}^{2}$ & 0.01 & 0.01 & 0.01 & 0.01 & 0.09 \\
\hline Obs. & 303 & 273 & 576 & 576 & 576 \\
\hline
\end{tabular}

Note. OLS regressions. The dependent variable is the growth rate of exports of firm $f$ for product $p$ to the United States between the period prior to the US dollar funding shock and the shock period. Significance levels: ${ }^{*} 10 \%,{ }^{* *} 5 \%,{ }^{* * *} 1 \%$. Standard errors in parentheses clustered at the firm level. Harmonized System 4-digit sector dummies included. Information about the use of hedging based on the EFIGE survey on European firms. 
Table 19: Quantification of the trade cost equivalent of the US dollar shock

\begin{tabular}{llll}
\hline \hline & \multicolumn{2}{l}{ Impact on exports (\% variation) } \\
Foreign dollar exposure (\%) & Baseline & WLS & OECD \\
Median $=0.47$ & -0.63 & -0.68 & -1.44 \\
Mean $=1.93$ & -2.57 & -2.78 & -5.93 \\
Treated (Avg. above median) $=3.94$ & -5.24 & -5.67 & -12.10 \\
Top $10 \%=6.40$ & -8.51 & -9.22 & -19.65 \\
Top 33\% (non-linear estimates) & -11.16 & & \\
& & & \\
& Trade cost shock equivalence $(\%$ increase) \\
& $(\rho=3.5$, i.e. trade elasticity $1-\rho=-2.5)$ \\
Foreign dollar exposure (\%) & Estimation & & \\
Median & Baseline & WLS & OECD \\
Mean & 0.25 & 0.27 & 2.37 \\
Treated (Avg. above median) & 1.03 & 1.11 & 4.84 \\
Top 10\% & 2.10 & 2.27 & 7.86 \\
Top 33\% (non-linear estimates) & 3.40 & 3.69 & \\
& 4.46 & & \\
\hline \hline
\end{tabular}

Notes: Authors' calculations based on the estimated elasticity of exports vis-à-vis firm-level exposure to US dollar funding shock ( $\beta=$ $\partial \Delta \ln \widetilde{v}_{f p, u s, t 1} / \partial U S D$ Exposure ). Elasticities: baseline $=-1.33$; Weighted Least Squares $=-1.44$; OECD countries in the group of reference destinations $=-3.07$. The trade cost equivalent is calculated for each level of exposure as the ratio of the estimated change in exports due to the firm-level dollar funding exposure over the predicted impact of a $1 \%$ increase in import tariffs (based on trade elasticities calibrated at $1-\rho$ $=-2.5$ taken from Berthou and Fontagné (ibid.)). 
XI. Appendix 


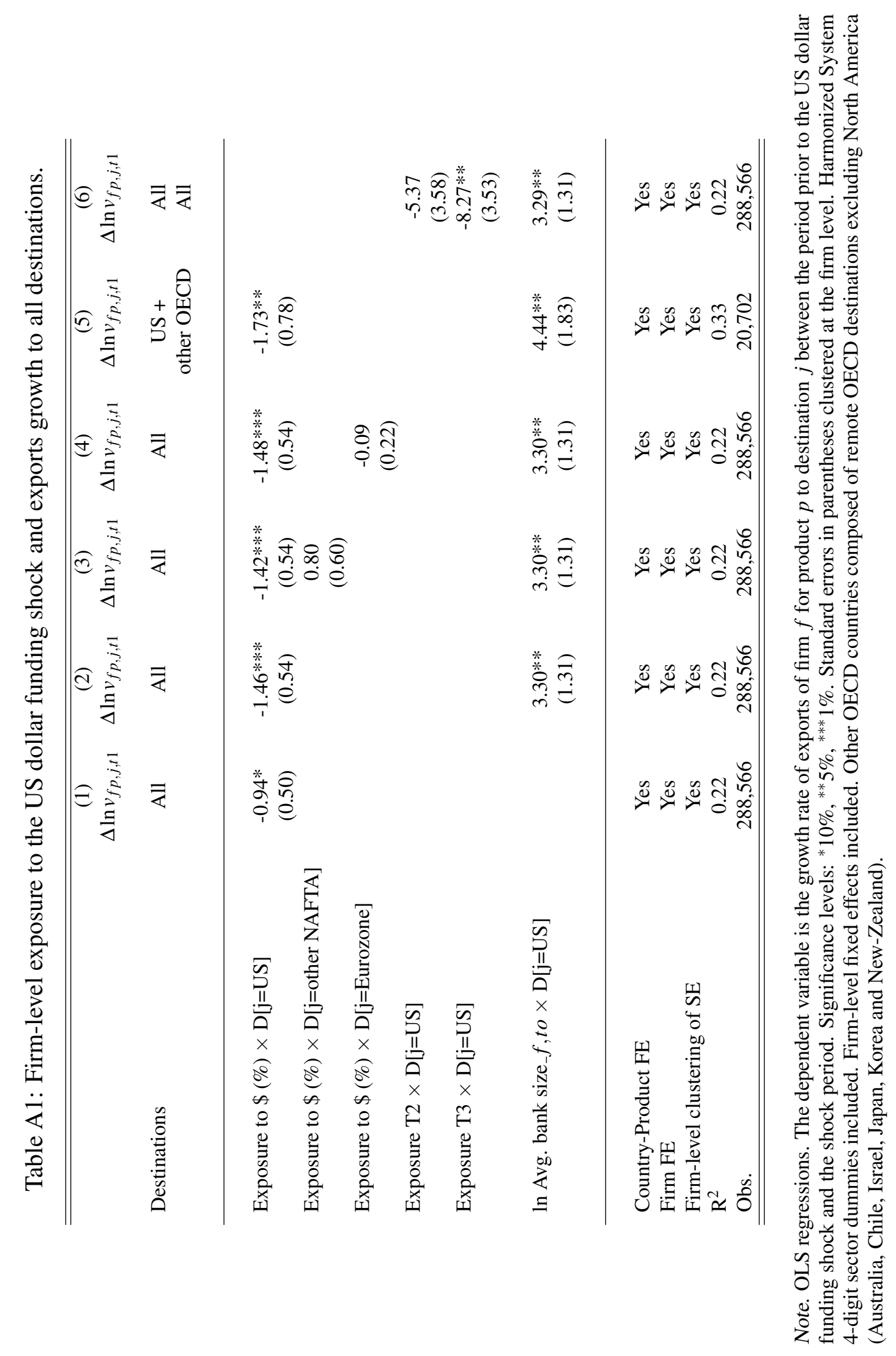


Table A2: Firm-level exposure to the US dollar funding shock and exports growth to the United States.

\begin{tabular}{|c|c|c|c|c|}
\hline \multirow{3}{*}{$\begin{array}{l}\text { Dep. var. } \\
\text { Estimator }\end{array}$} & (1) & (2) & (3) & (4) \\
\hline & \multicolumn{4}{|c|}{ Absolute variation of exports: $\Delta \ln v_{f p, u s, t 1}$} \\
\hline & \multicolumn{2}{|c|}{ OLS } & \multicolumn{2}{|c|}{ PSW } \\
\hline Exposure to Dollar shock (\%) & $\begin{array}{l}-1.19^{*} \\
(0.66)\end{array}$ & & $\begin{array}{c}-2.05^{* *} \\
(0.79)\end{array}$ & \\
\hline Dollar exposure dummy, 2 nd third $f, t o$ & & $\begin{array}{c}-8.82^{* *} \\
(4.05)\end{array}$ & & $\begin{array}{l}-8.00^{*} \\
(4.61)\end{array}$ \\
\hline Dollar exposure dummy, 3 rd third $f, t o$ & & $\begin{array}{c}-11.48^{* * *} \\
(4.14)\end{array}$ & & $\begin{array}{c}-14.41^{* * *} \\
(4.89)\end{array}$ \\
\hline ln Avg. bank size ${ }_{f, t o}$ & $\begin{array}{c}1.45 \\
(1.58)\end{array}$ & $\begin{array}{c}2.38 \\
(1.57)\end{array}$ & $\begin{array}{c}4.33 \\
(6.70)\end{array}$ & $\begin{array}{c}4.79 \\
(6.74)\end{array}$ \\
\hline ln number of banks $f, t o$ & $\begin{array}{c}0.13 \\
(2.08)\end{array}$ & $\begin{array}{c}1.69 \\
(2.23)\end{array}$ & $\begin{array}{c}2.81 \\
(2.50)\end{array}$ & $\begin{array}{l}4.44^{*} \\
(2.59)\end{array}$ \\
\hline ln total exports $f, t o$ & $\begin{array}{l}-2.08^{*} \\
(1.08)\end{array}$ & $\begin{array}{l}-1.92^{*} \\
(1.08)\end{array}$ & $\begin{array}{l}-1.16 \\
(1.52)\end{array}$ & $\begin{array}{l}-1.05 \\
(1.52)\end{array}$ \\
\hline In theoretical markup m $_{f, t o}$ & $\begin{array}{c}1.28 \\
(10.02)\end{array}$ & $\begin{array}{c}0.14 \\
(10.11)\end{array}$ & $\begin{array}{c}-1.67 \\
(24.49)\end{array}$ & $\begin{array}{c}-2.85 \\
(24.17)\end{array}$ \\
\hline ln total employment ${ }_{f, t 0}$ & $\begin{array}{c}2.07 \\
(1.46)\end{array}$ & $\begin{array}{c}2.16 \\
(1.45)\end{array}$ & $\begin{array}{c}1.04 \\
(1.86)\end{array}$ & $\begin{array}{c}1.08 \\
(1.85)\end{array}$ \\
\hline HS4 Product FE & Yes & Yes & Yes & Yes \\
\hline Firm-level clustering of SE & Yes & Yes & Yes & Yes \\
\hline $\mathrm{R}^{2}$ & 0.09 & 0.09 & 0.13 & 0.13 \\
\hline Obs. & 7,726 & 7,726 & 5,548 & 5,548 \\
\hline
\end{tabular}

Note. OLS regressions. The dependent variable is the growth rate of exports of firm $f$ for product $p$ to the United States between the period prior to the US dollar funding shock and the shock period. Significance levels: ${ }^{*} 10 \%,{ }^{* *} 5 \%,{ }^{* * *} 1 \%$. Standard errors in parentheses clustered at the firm level. Harmonized System 4-digit sector dummies included. Estimator: OLS stands for Ordinary least Squares; PSW for Propensity Score Weighting. 